Florida International University FIU Digital Commons

$3-6-2002$

\title{
Analysis and comparison of the moral development of students required to graduate with an ethics course
}

Mary Feeney Bonawitz

Florida International University

DOI: $10.25148 /$ etd.FI14051188

Follow this and additional works at: https://digitalcommons.fiu.edu/etd

Part of the Business Administration, Management, and Operations Commons

\section{Recommended Citation}

Bonawitz, Mary Feeney, "Analysis and comparison of the moral development of students required to graduate with an ethics course" (2002). FIU Electronic Theses and Dissertations. 1726.

https://digitalcommons.fiu.edu/etd/1726 
Miami, Florida

\begin{abstract}
ANALYSIS AND COMPARISON OF THE MORAL DEVELOPMENT OF STUDENTS REQUIRED TO GRADUATE WITH AN ETHICS COURSE
\end{abstract}

\author{
A dissertation submitted in partial fulfillment of the \\ requirements for the degree of \\ DOCTOR OF PHILOSOPHY \\ in
}

BUSINESS ADMINISTRATION

by

Mary Feeney Bonawitz

2002 
To: Dean Joyce J. Elam

College of Business Administration

This dissertation, written by Mary Feeney Bonawitz, and entitled Analysis and Comparison of the Moral Development of Students Required to Graduate with an Ethics Course, having been approved in respect to style and intellectual content, is referred to you for judgment.

We have read this dissertation and recommend that it be approved.

Dana L. Farrow

Ena Rose-Green

Clark Wheatley

Felix Pomeranz, Major Professor

Date of Defense: March 6, 2002

The dissertation of Mary Feeney Bonawitz is approved.

Dean Joyce. J. Elam

College of Business Administration

Dean Douglas Wartzok

University Graduate School

Florida International University, 2002 
(C) Copyright 2002 by Mary Feeney Bonawitz

All rights reserved. 


\section{DEDICATION}

I dedicate this dissertation to my husband, Irving $\mathrm{M}$. Bonawitz, $\mathrm{PhD}, \mathrm{CPA}$. Without his patience, suggestions, guidance, and most of all love, this dissertation would not have been completed. 


\section{ACKNOWLEDGMENTS}

I wish to thank the members of my committee for their unending patience, support and suggestions. They have been shining examples to me and encouraged me to remain confident in my abilities to succeed. From the School of Business Administration, Dana Farrow, took time from his schedule to serve on a committee in a discipline other than his own. I appreciate Ena Rose-Green's thoughtful commentary on my research methodology and hypotheses. Clark Wheatley's great sense of humor made all his critiques interesting which aided my writing and learning.

My deepest appreciation must go to Dr. Felix Pomeranz, my major professor, for his encouragement and confidence to help to reach my goals. He kept me on track with his gentle prodding despite the many delays due to my husband's illness. He has my eternal gratitude and deepest respect. 
ABSTRACT OF THE DISSERTATION

ANALYSIS AND COMPARISON OF THE MORAL DEVELOPMENT OF

STUDENTS REQUIRED TO GRADUATE WITH AN ETHICS COURSE

by

Mary Feeney Bonawitz

Florida International University, 2002

Miami, Florida

Professor Felix Pomeranz, Major Professor

Accounting students become practitioners facing ethical decision-making challenges that can be subject to various interpretations; hence, the profession is concerned with the appropriateness of their decisions. Moral development of these students has implications for a profession under legal challenges, negative publicity, and government scrutiny. Accounting students moral development has been studied by examining their responses to moral questions in Rest's Defining Issues Test (DIT), their professional attitudes on Hall's Professionalism Scale Dimensions, and their ethical orientation-based professional commitment and ethical sensitivity. This study extended research in accounting ethics and moral development by examining students in a college where an ethics course is a requirement for graduation.

Knowledge of differences in the moral development of accounting students may alert practitioners and educators to potential problems resulting from a lack of ethical understanding as measured by moral development levels. If student moral development levels differ by major, and accounting majors have lower levels than other students, the 
conclusion may be that this difference is a causative factor for the alleged acts of malfeasance in the profession that may result in malpractice suits.

The current study compared 205 accounting, business, and nonbusiness students from a private university. In addition to academic major and completion of an ethics course, the other independent variable was academic level. Gender and age were tested as control variables and Rest's DIT score was the dependent variable. The primary analysis was a $2 \times 3 \times 3$ ANOVA with post hoc tests for results with significant $p$-value of less than 0.05 .

The results of this study reveal that students who take an ethics course appear to have a higher level of moral development $(\mathrm{p}=0.013)$, as measured by the (DIT), than students at the same academic level who have not taken an ethics course. In addition, a statistically significant difference $(p=0.034)$ exists between freshmen who took an ethics class and juniors who did not take an ethics class. For every analysis except one, the lower class year with an ethics class had a higher level of moral development than the higher class year without an ethics class. These results appear to show that ethics education in particular has a greater effect on the level of moral development than education in general. Findings based on the gender specific analyses appear to show that males and females respond differently to the effects of taking an ethics class. The male students do not appear to increase their moral development level after taking an ethics course $(p=0.693)$ but male levels of moral development differ significantly $(p=0.003)$ by major. Female levels of moral development appear to increase after taking an ethics course $(p=0.002)$. However, they do not differ according to major $(p=0.097)$. 
These findings indicate that accounting students should be required to have a class in ethics as part of their college curriculum. Students with an ethics class have a significantly higher level of moral development. The challenges facing the profession at the current time indicate that public confidence in the reports of client corporations has eroded and one way to restore this confidence could be to require ethics training of future accountants. 
CHAPTER

PAGE

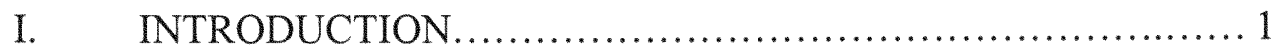

Accounting Background....................................... 1

Ethics in Education........................................... 3

II. LITERATURE REVIEW .................................... 7

Measuring Moral Development ................................. 7

Ethics Research in Business.........................................10

Ethics Research in Accounting before 1990....................... 14

Ethics Research in Accounting - The AICPA Code of Conduct...... 16

Ethics Research in Accounting - Defining Issues Test (DIT)........ 17

III. HYPOTHESES DEVELOPMENT ............................ 21

IV. RESEARCH METHODOLOGY .............................. 24

Research Design and Explanatory Variables.......................25

Subjects......................................................27

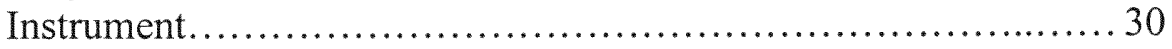

Procedure ................................................... 30

V. RESULTS ............................................. 31

VI. DISCUSSION, LIMITATIONS AND FUTURE RESEARCH....... 42

Discussion.................................................. 42

Limitations................................................. 49

Future Research.......................................... 51

LIST OF REFERENCES ......................................... 53

APPENDICES .................................................. 58

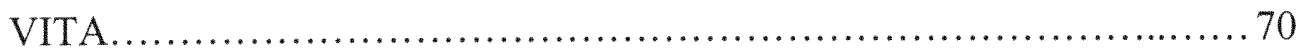




\section{LIST OF TABLES}

TABLE

PAGE

1. Kohlberg's Cognitive Moral Development 8

2. Rest (1979a) "P"scores 10

3. Variables and Coding Descriptions 25

4. Final Sample of Subjects 29

5. DIT SCORES 32

6. "P" SCORE ANOVA MODEL 35

7. Mean Principled "P" Scores 37

8. "P" Score General Linear Regression Model 38

9. Mean Principled "P" Scores for All Students in These Studies 40

10. DIT Scores of All Student Subjects by Major, Year and Level 41

11. Mean Principled "P" Scores of All Students in These Studies 43

12. DIT Scores of All Student Subjects by Major, Year and Level 44 


\section{Chapter 1. INTRODUCTION}

\subsection{Accounting Background.}

Professional conduct and ethics were not formally addressed by the accounting profession until the mid 1980s. Robert Sack, then chief accountant for the Securities and Exchange Commission (SEC) Division of Enforcement, expressed concern over encroaching ills in the profession (Sack, 1985). Some of the concerns were opinion shopping, lack of communication with regulators regarding audit client financial irregularities, and a perceived lack of independence in audits of management advisory clients. The failures of savings and loan institutions and junk bonds debacles of the late 1980s and early 1990s (Armstrong, 1993; Epstein and Spalding, 1993; Mednick, 1987) resulted in accusations of income smoothing by corporations such as General Electric, Mattel, W. R. Grace and NationsBank (DePree and Grant, 1999) and improper write-offs (Lazere, 1997; Greenman and Sherman, 1999). Due to its effect on the market price of a company's stock, income smoothing was of great concern to SEC Chairman Levitt. (This accounting practice arises when a company's management interferes in the financial reporting process in order to distort the true earnings.)

During the 1980s the United States Congress led by Congressmen Jack Brooks, John Dingle, and Ron Wyden, launched investigations into the financial problems of audited corporations. The Dingle sub-committee (1985) initiated intensive investigations of the accounting profession's independence and quality of performance. In 1986, 
Representative Wyden ${ }^{1}$ introduced a bill requiring auditors to expand the scope of their audits to include the detection of fraud (Armstrong, 1993). In the same year, the U. S. Comptroller General issued a report on the problems resulting from the lack of quality in CPA audits of governmental units (Bowsher, 1986). These problems were CPAs' failure to follow Generally Accepted Auditing Standards including lack of work papers, insufficient supervision of staff and no review of work papers and reports. The same year the SEC initiated greater imposition of Rule 2(e) (Epstein and Spalding, 1993). This rule penalizes infractions by banning a CPA firm from practice before the SEC on a temporary or permanent basis.

The SEC's concern with the accounting profession has increased since the 1980s. In May 2000, SEC Chairman Arthur Levitt criticized accountants' compliance with SEC rules and requested that the Big Five accounting firms perform self-assessments of their compliance (Tie, 2000). Levitt was most alarmed about independent auditors said to keep clients happy by turning a blind eye to clients' earnings management activities. Recent headlines have reported numerous accounts of CPAs supposedly unaware of their clients' reporting irregularities. Tyco International and MicroStrategy received extensive coverage in the media for their declining stock prices after they had to restate earnings. Industry leaders, such as America On-line and Microsoft, have not escaped the criticism of analysts. These two giants of the technology revolution were under SEC investigation for revenue recognition violations by not reporting earnings in the proper accounting period. Bukics and Fleming (2000) reported that the first consideration to deter improper revenue recognition is for management to set a "tone at the top" to create an environment

${ }^{1}$ Representative Wyden's bill H.R. 4886 failed to pass in Congress. 
that communicates what is and is not acceptable behavior in the corporate culture. This concept of setting a tone at the top was earlier mentioned in the 1987. Treadway Commission Report. The report stated "the tone that the top managements of public accounting firms set is just as important in the firms as that set by top managements in public companies."

\subsection{Ethics in Education}

If management's tone sets an acceptable level of behavior in the workplace but the environment still suffers from unacceptable behavior, is it possible that the unacceptable ethical behavior was learned in childhood? How pervasive is the unethical conduct of youth? Current research finds that between $75 \%$ and $98 \%$ of all college students cheated in high school (Kleiner and Lord, 1999); in many cases, the students were aided by their parents (Loftus and Smith, 1999). Indeed, the November 22, 1999 issue of U.S. News \& World Reports (Loftus and Smith, 1999) states cheating and academic dishonesty often begin in grade school. For example, the unethical behavior in education is perpetuated by on-line term papers for sale and delayed transmission of questions on national standardized exams. Kleiner and Lord (1999) report this conduct is further manifested by padding resumes when job hunting.

Moral development of accounting students has implications for a profession under legal challenges and government scrutiny. Students become accountants and business leaders who make decisions that can be subject to a variety of interpretations. The profession is concerned with the appropriateness of these decisions ranging from earnings 
management (DePree and Grant, 1999), underreporting time on client engagements (Ponemon, 1992), to lack of independence on attestation services (Ponemon and Gabhart, 1990), and willingness to "commit fraud" by adjusting write-offs to fix the bottom line (Lazere, 1997). Moral development of future accountants is especially relevant given the rash of negative events facing the profession today. These are caused, in part, by a litigious business environment, continued "downsizing" of major corporations, and mergers of the largest accounting firms (Ponemon, 1993).

The case for teaching ethics in the accounting and business school curriculum was proposed as early as the Treadway Commission Report (1987) and Bedford Report (1986). Langenderfer and Rockness (1989) addressed the need to incorporate ethics cases into accounting courses to better prepare students for the challenges they might face on the job. This need for ethics in accounting courses was an element of Position Statement Number Two of the Accounting Education Change Commission (1992). The Statement suggested that students in the first accounting course should be exposed to the accounting profession's ethics and the public responsibilities of the profession. However, a study of the coverage of ethics in these texts shows significant variation (Bracken and Urbancic, 1999). They reported that some texts had as much as $7.1 \%$ of the pages having a reference to ethics; while others had less than $1 \%$ of the pages referring to ethics. In addition, records maintained by the Association to Advance Collegiate Schools of Business (AACSB) do not report information on accounting programs that require specific ethics courses. According to Daniel LeClair, AACSB Director of Knowledge Services, few accounting programs require specific ethics courses. 
Knowledge of differences in the moral development of students who attend a university where at least one ethics course is required in order to graduate, vis-à-vis students who are not required to take an ethics course as part of their curriculum, may alert practicing accountants and educators to potential problems resulting from a lack of ethical understanding. Ponemon (1993) summarized findings to date and reported "ethical reasoning has been shown to influence accounting judgment such as audit independence, the disclosure of sensitive information, the assessment of audit evidence, and the detection of fraudulent financial information." Since ethics courses are a new addition to the accounting curriculum, the average CPA has not had this requirement during his or her university years. Bartel (1990) reported that failure to comply with professional ethics might be found in court to be clear evidence of malfeasance that often results in findings of malpractice. If the moral development level of students who are not exposed to an ethics course in a university is lower than that of students who take an ethics course, the conclusion may be that the comparative low moral development level of the average CPA (Armstrong 1987, Ponemon 1992) is a causative factor for misinterpretation of professional ethics.

Findings of a lack of professional ethics may be the starting point for the resolution of a situation that could, if not rectified, substantially change the professional status of the CPA or even destroy it. The profession may be forced into further consolidations due to the cost of malpractice insurance and into continued lengthy and expensive lawsuits. Regulation of the profession may; for example, occur through increased government control (Armstrong, 1993). The knowledge of differences between students exposed to ethics in the undergraduate curriculum and those who have not may 
have implications for educators developing accounting curriculums to comply with the 150-hour law. "Perspectives on Education: Capabilities for Success in the Accounting Profession" (Kullberg, Groves, Gladstone, Horner, Scanlon, O’Malley, Cook, and Kangas 1989), a document prepared by the managing partners of the Big Six accounting firms, that specifies the general knowledge skills that are desired in a student's education.

This research examines differences in the level of moral development between students who have taken an ethics class and those who have not, after controlling for academic major and academic level. Shaub (1994) examined students and auditors who had a college ethics course and compared the results to those of students and auditors who had not taken this course. In that study, however, there is the possibility of selfselection bias since the class was not required for graduation. Students who elect to take an ethics course that is not a graduation requirement may have different ethical awareness than other students. This study examines students who are not able to self-select into or out of an ethics course, but who are required to complete the course in order to meet the requirements for graduation. This is an innovative contribution to the accounting ethics literature since prior research has not examined students for whom ethics was not a choice.

The remainder of this paper is organized as follows: Section II reviews the pertinent literature for ethics research in accounting, including the foundations of moral development theory used in the accounting research to date. Section III develops hypotheses to test the moral development levels of the students. Section IV describes the research methodology. Section V presents the findings and their analyses. Section VI discusses potential contributions, limitations and future research. 


\section{Chapter 2. LITERATURE REVIEW}

\subsection{Measuring Moral Development}

Moral development psychology is an established field of research developed by child psychologist Jean Piaget (1932). His research in moral development was preceded by his early studies of developmental psychology in France. He found that knowledge is a process of growth in the brain that is built by logically rooted structures starting with lower-level logical means and building in adulthood to higher-level logical processes. $\mathrm{He}$ found that the cognitive modes of children initially and dramatically differ from those of adults. His theories of psychological development were tested and refined while working at a boy's institution in France. Later as Director of the Institute of Educational Sciences, University of Geneva, he researched his theories of moral development in children and the foundations needed to develop moral awareness in adults.

Lawrence Kohlberg (1969) built on Piaget's research to emphasize the cognitive basis of moral judgment and its effect on moral action. Like Piaget, Kohlberg based his theory on cognition processing; stages in the organization of moral development; research into the process of making a moral judgment; and research of children at many different stages (Rest 1994). Kohlberg's theory of Cognitive Moral Development (CMD) provided for six unique stages of moral development, which can be grouped into three levels of CMD, each with two stages. These stages are based on the concept that moral development is a monotonically increasing function over time (Jeffrey 1993). According 
to Kohlberg (1969), individuals should develop the higher stages of moral cognition as they progress through the experiences of life.

\section{TABLE 1}

Kohlberg's Cognitive Moral Development

\begin{tabular}{|l|l|l|}
\hline Levels & Lower stage & Upper stage \\
\hline $\begin{array}{l}\text { Pre-conventional } \rightarrow \text { the focus } \\
\text { is on the individual only. }\end{array}$ & $\begin{array}{l}\text { Stage } 1 \rightarrow \text { focus on } \\
\text { obedience and punishment } \\
\text { orientation. }\end{array}$ & $\begin{array}{l}\text { Stage } 2 \rightarrow \text { focus on } \\
\text { instrumental purpose } \\
\text { and exchange. }\end{array}$ \\
\hline $\begin{array}{l}\text { Conventional } \rightarrow \text { the focus is } \\
\text { on relationships in a group. }\end{array}$ & $\begin{array}{l}\text { Stage } 3 \rightarrow \text { focus on } \\
\text { interpersonal accord, } \\
\text { conformity, mutual } \\
\text { expectations. }\end{array}$ & $\begin{array}{l}\text { Stage } 4 \rightarrow \text { focus on } \\
\text { social accord and system } \\
\text { maintenance. }\end{array}$ \\
\hline $\begin{array}{l}\text { Post-conventional } \rightarrow \text { the } \\
\text { focus is on the inner self and } \\
\text { personally held principles. }\end{array}$ & $\begin{array}{l}\text { Stage } 5 \rightarrow \text { focus on social } \\
\text { contact and individual } \\
\text { rights. }\end{array}$ & $\begin{array}{l}\text { Stage } 6 \rightarrow \text { focus on } \\
\text { universal ethical } \\
\text { principles. }\end{array}$ \\
\hline
\end{tabular}

Kohlberg's (1969) levels and stages of CMD are summarized in Table 1. These stages describe how individuals learn to determine right from wrong. Kohlberg's stagesequence theory posits that the higher the developmental stage, the greater the level of moral development. Kohlberg's model emphasizes the cognitive or reasoning aspect of moral decision-making rather than an individual's behavior. Psychological research, however, has shown that there is a positive correlation between relatively high moral judgment, and what is considered moral behavior, such as honesty, resistance to 
temptation, and charity (Kohlberg and Candee 1984). Rest (1990) wrote that "moral judgment draws on the basic conceptual frameworks by which a subject analyzes a social-moral problem and judges the proper course of action" (P4.1) they should take. Each person faces a moral dilemma where a choice must be made.

Kohlberg and Candee (1984) found that an individual uses their psychological understanding of right and wrong, prior situations of moral choice, the effect of social events on cognitive processes, and then makes a dynamic judgment that they act upon to resolve the dilemma. Ashton and Ashton (1995) found that judgment performance is the result of "the joint effects of cognition and incentives" (P22). Kohlberg and Candee (1984) reported that subjects who understand right from wrong would usually carry that moral understanding into behavior by making the correct moral judgment.

Although Kohlberg's stages of CMD are discrete, Rest (1979) designed an objective test of Kohlberg's CMD using a continuous scale. His multiple-choice Defining Issues Test (DIT) (see Appendix B) provides a "P" (Principled) score to measure a subject's responses to a set of three to six cases. These cases require a subject to decide a moral dilemma that they may face in their daily lives. Although the measurement approaches are different, the larger the "P" score, the higher the probability that a subject's thinking is at a high CMD level. The "P" score ranges from 0 to 95 and scores under 50 indicate the subject does not recognize moral problems nor make moral judgments with the same cognition that moral philosophers do.

The DIT does not rate or portray a subject's personality, value as a human being, or sociability. DIT evaluation by the "P" scores is an assessment of conceptual adequacy of moral thinking. The subject is not to present their reasons for their choice to resolve the 
dilemma, but to rank the items given that most strongly influence choice. The "P" score interprets the "relative importance a subject gives to principled moral considerations in making a decision about ethical dilemmas" (Rest 1979b, 5.2) and is based on rankings the subject gives to "items representing Stages 5 and 6, principled moral thinking" (Rest 1994, 13).

Rest (1979a) conducted a large-scale study using the DIT. The test was given to more than 4,000 subjects ranging from college students to adults in the workplace. Table 2 summarizes the data from this study. Rest found support for Kohlberg's (1969) CMD and that education was positively correlated with higher "P" scores. Since that study the DIT has been used in more than 500 research projects involving moral development.

TABLE 2

Rest (1979a) "P" scores

\begin{tabular}{|l|l|l|l|}
\hline Group: & Number & Mean "P" score & Standard Deviation \\
\hline College undergraduates & 2,479 & 42.3 & 13.2 \\
\hline Graduate students & 183 & 53.3 & 10.9 \\
\hline Adults & 1,149 & 40.0 & 16.7 \\
\hline
\end{tabular}

\subsection{Ethics Research in Business}

One of the earliest studies on ethics in business was a Harvard University survey by Baumhart (1961). He surveyed business executives to gather empirical evidence on unsubstantiated claims that numerous executives act in an unethical manner in their business relationships. Baumhart contacted 796 executives, and asked them about their 
attitudes, behavior, and experiences in the workplace. He found that almost $50 \%$ reported conflicts between company interests and personal ethics. The greatest conflicts were found to arise from: 1) firings and layoffs, 2) honesty in communication, and 3) pricing (including price collusion).

Brenner and Molander (1977) updated the 1961 Harvard Business Review study of business ethics. They added the concepts of social responsibility and conflicts in relations with individuals. The updated study found that respondents were more cynical of the ethics of their peers than were respondents in the earlier study. In addition, the 1977 study found evidence that ethical standards had declined and that practices that were once ethically suspect were now common. Conflicts between company interests and personal ethics were found to have increased in regard to honesty in communication, but to have decreased for personnel and pricing issues. In addition, there were new conflicts reported for the issues of: fairness and discrimination, honesty in executing contracts, and miscellaneous law breaking. This study provided the foundation for the work of Arlow and Ulrich $(1980,1988)$ and Trevino (1986) in business ethics and moral development.

Arlow and Ulrich (1980) examined the ethical behavior of business executives and undergraduate business students. They tested students on scales measuring personal business ethics and social responsibility. They found that students who took a university course that had a strong ethics component had a higher post-test score than pretest score, on the issues of personal business ethics and social responsibility. They then gave the same test to a group of business executives and compared the executives scores with those of the students. Arlow and Ulrich found that the executives had significantly 
higher scores on personal business ethics than either the pre or post test groups of students. The students, however, had higher scores than the executives on the issue of social responsibility. The researchers found support for the conjecture that business students reject some aspects of corporate life, such as price-fixing schemes, misleading advertising and actions that limit fair competition. Their finding cannot, however, be extended to a rejection of the contemporary business ethics tested in the study. This raises the question of whether the personal business ethics of students can be strengthened.

An interactionist model of ethical decision-making based on Kohlberg's (1969) Theory of CMD was proposed by Trevino (1986) to explain ethical behavior. The model recognizes that individual elements, such as moral development, need to function with situational elements, such as the work culture, to predict and clarify how ethical decisions are reached. Trevino found that ethical decision-making is a constant in the uncertain market environment where "multiple stakeholders, interests, and values are in conflict" (P601) and the legal system is not consistent ${ }^{2}$. Kohlberg's CMD provided construct definition for the theoretical foundation of the model and the measurement tools. The model was expected to be an addition to the conceptual base of understanding ethical decision-making in organizational settings.

Since individuals search for guidance in resolving ethical business dilemmas (Hosmer 1988, Loeb 1988, and Greenman and Sherman 1999), educational institutions have a critical role to play in training students to make informed and morally correct

2 The relationship between e-commerce and privacy rights is a current example of such conditions. 
business decisions. Trevino and McCabe (1994) suggested that ethics education for business students does not provide enough comprehensive coverage to provide the guidance required by current market conditions. They found that ethics education is not a required course in most universities, and that the courses that are offered lack the ability to "stimulate students cognitive moral development by exposing them to moral reasoning" (P407) that is higher than their current level of reasoning. They suggested that universities' "experience with honor codes" (P414) provides an opportunity to create environments "where students, faculty and administrators come together to learn about ethics" (P414) through ethical performance.

Lazere (1997) interviewed corporate CFOs' regarding concerns with business students' ethical orientation and then asked business school faculty to respond to the issues raised by the CFOs. These executives told Lazere that emphasis needs to be placed on the decision-making process in reaching an ethical decision and not just on the ability to know right from wrong. Lazere focused on executives' responses to an experiment by Brief, Dukerich, Brown and Brett (1996) that found over three-fourths of MBA students were willing to commit fraud to increase reported earnings. Lazere found support for the belief that financial reporting practices of the corporation affect the behavior of managers. At the same time, she reported that ethics education could train students to distinguish ethical dilemmas and to resolve them to the benefit of both the individual and the organization. The AACSB requires ethics to be covered in some form by its member schools but does not specifically require a separate ethics course or even coverage in a business class. Some AACSB institutions leave ethics to the philosophers. However, other schools that teach ethics in the business curriculum provide coverage 
over a wide continuum from mentioning the ethics in one class to a track of ethics courses in the specific business disciplines.

Greenman and Sherman (1999), in an examination of recent research on executives, business students, and business school deans, reported that while young executives were uncomfortable with violations of legal and ethical standards, they felt that these violations would aid their career advancement. Business school students were unable to see the difference between "high moral self-image and actual unethical behavior" (P173) in the workplace. These students reported to the authors that they believed they had high ethical standards yet, from the same subjects "only 5.2\% claimed that they did not cheat at all" (P173). Administrators at business schools were surveyed on issues ranging from pre-dated contributions for manipulating taxable income to the admission of unqualified students upon the request of a major donor. In these situations, the authors reported that many of the deans would proceed with an act that some might consider "questionable" (P174), such as deleting the records of a student with violations of the school's honor code, for a donation. Other questionable behavior that the deans acknowledged was accepting backdated checks for donations of a different tax year, knowing that it was a violation of IRS Section 6701, or the admittance of an unqualified applicant to the MBA program in exchange for a large donation.

\subsection{Ethics Research in Accounting before 1990}

An early empirical study by Finn, Chonko, and Hunt (1988) examined the nature and extent of ethical problems faced by AICPA members. They surveyed members of 
the AICPA (excluding educators) to identify the most important ethical problems facing senior level AICPA members, and to learn how the AICPA members viewed these problems. The most frequently cited problems faced by the respondents were: tax fraud and alterations of tax information, conflicts of interest and independence, alterations of financial statements, and fee issues. Overall, the CPAs responding to the survey believed that the opportunities exist in the profession for unethical behavior, but professional success can be achieved without resorting to such actions. The respondents believed that ethical problems are reduced when partners in firms reprimand other firm employees for unethical behavior.

Loeb (1988) addressed the issue of teaching ethics to accounting students. $\mathrm{He}$ stated that the need for teaching ethics is imperative due to the environment in which accountants practice. Most important are the codes of conduct of the professional associations and state licensing boards and the dilemmas in the decision-making processes of accounting. Students need to be able to tie their "accounting education to moral issues" (P321) and recognize that the choices they make for their clients or their employers have ethical implications to the profession. Accounting is increasingly complex which leads to choices in accounting policies and practices. Some of these choices may lead to errors in moral judgment if students have not received training in ethics. Loeb believes that the accounting environment is dynamic and that students need to receive ethics education to aid in making moral judgments.

Basic issues in ethics education and problems associated with the integration of ethics into the accounting curriculum were addressed by Langenderfer and Rockness (1989). They stated that students need to 1) be made aware of the potential ethical 
conflicts in accounting careers and 2) taught how to resolve ethical conflicts to the satisfaction of all parties. They believe that students need to discuss the issues surrounding business ethics and learn how to gather sufficient information for ethical decision-making while they are still students. If they do not gather the necessary information, then they may make "a bad or, at least, a poorer decision" (P 61) in their career than if they would have had if they discussed a similar situation in an academic setting. Langenderfer and Rockness support Kohlberg's theory that college students' moral values can be strengthened through the education process. They support the notion that college students should complete at least one "philosophy-based course" during their college years.

\subsection{Ethics Research in Accounting - The AICPA Code of Conduct}

Beets (1992) examined practitioners' problems with implementing the revised AICPA Code of Professional Conduct (1991). The AICPA Code differed from many state society codes and the ethics rules of state licensing boards. Some of the more contentious differences were concerning referral fees, contingent payments and commissions. The accountants surveyed by Beets were questioned regarding their knowledge of ethics. Beets' results showed that $38 \%$ of the subjects continued their ethics education after the completion of their formal university training, and that of those, $65 \%$ (or $25 \%$ of the total) had attended CPE programs in which ethics was a topic. The remaining $62 \%$ of those surveyed had not received any ethics instruction after they completed formal university training, and were unfamiliar with the code-of-conduct 
changes. Beets suggests that this lack of knowledge could result in widespread compromises by accountants placed in situations where an ethical judgment must be made. He further suggested that state accountancy boards, CPA firms, and the AICPA facilitate understanding of the changes in the code-of conduct through the creation of CPE courses specifically related to ethics.

Ward, Ward and Wilson (1996) examined students' ethical perceptions and attitudes when presented with situations concerning the AICPA Code of Professional Conduct. They found that students learn how accountants are expected to behave from contact with educators and practitioners. "When internalized" (P148), students will develop opinions "of how CPAs will or should behave when faced with ethical decisions" (P148). Ward, Ward and Wilson's findings confirm that education and the passage of time can alter students' ideas of acceptable professional behavior. The exposure and subsequent resolution of conflicts in ethical judgments at the college level may prevent errors in decision-making after the student enters the work force.

\subsection{Ethics Research in Accounting - Defining Issues Test (DIT)}

Armstrong (1987) was the first accounting researcher to use the DIT to examine moral development in the accounting profession. As discussed earlier the DIT provides a Principled ("P") score that measures a subject's responses to a set of three to six cases. These cases require a subject to decide a moral dilemma that they may face in their daily lives. The "P" score ranges from 0 to 95 and the greater the "P" score, the higher the probability that a subject's thinking is at a high $\mathrm{CMD}$ level. She examined ethics from a 
moral development perspective and not the prescriptive rules of the AICPA Code of Conduct and state licensing boards. The understanding of ethics through the moral maturity of CPAs was tested by Armstrong based upon the theory of cognitive moral development (CMD) proposed by Kohlberg (1969) and used in Trevino's 1986 model.

At Kohlberg's highest levels (stages five and six), Armstrong found that individuals are guided by inner principles that have been developed through the process of CMD. Armstrong compared the "P" score of college educated CPAs, with those of the subjects in Rest's 1979a study, as discussed previously. She mailed a questionnaire that included a three-part version of Rest's DIT, instructions and a request for demographic data to a random sample of practicing CPAs. Armstrong compared her results with the DIT "P" scores from Rest's subjects of college undergraduates, graduate students and adults in the general population. The results suggested that practicing CPAs have reached the moral maturation level of adults in general, but not the level of college students and much less than the level of graduate students in Rest's study.

While it seems likely, that practicing CPAs would score at least at the minimum level for college students, the results from Armstrong's study did not support that expectation. The college education of the CPAs did not appear to have inspired a continued moral maturation. Instead, the moral development of practicing CPAs, as measured by the "P" score, was found to be lower than both graduate and undergraduate students. Despite the surprising results that CPAs have a statistically significant lower level ( $\mathrm{p}$-value $=0.05$ ) of moral development than students do, Armstrong found these results might encourage inclusion of ethics in the accounting curriculum. This research provided the foundation for many successive studies in accounting using the DIT. 
Appendix A summarizes the research topic studied and provides a summary of Armstrong (1987) and successive accounting studies of ethics in the profession and education.

Ponemon and Glazer (1990) extended Armstrong (1987) by examining the ethical development of students and graduates of accounting programs at two educational institutions. They employed the Defining Issues Test (DIT) to study the "influence of college education and professional practice on an individual's ethical development" (P 195). Ponemon and Glazer chose academic institutions with very different academic and operating philosophies. One test site was a public institution in the northeastern United States and the other was a private liberal arts institution in the same geographic area. Their results were not consistent with Armstrong (1987). Ponemon and Glazer found that alumni from the private institution achieved higher DIT "P" scores than the alumni from the state institution and that alumni from the public institution achieved DIT "P" scores consistent with Armstrong's (1987) findings for accounting graduates. Other findings from their research were that seniors and alumni from the institutions under study achieved higher DIT "P" scores than freshmen from the same institution, and that the alumni "P" score variation was significantly lower than the variation within the students' ranks at both institutions. Ponemon and Glazer argued that different educational philosophies were responsible for higher "P" scores of accounting students at the liberal arts institution. They caution, however, that only a longitudinal study could support such a conclusion.

The differences found by Ponemon and Glazer (1990) provided the impetus for Jeffrey (1993) to study the moral development of students at a single institution. Jeffrey 
theorized that the differences in Ponemon and Glazer (1990) were the result of the different moral atmosphere of each institution that fostered the moral development of the students. Jeffrey's subjects were lower division students (freshmen and sophomores) and seniors in three different majors. Her results supported Ponemon and Glazer's (1990) finding that lower division students in the study had lower DIT "P" scores than seniors in each major. In addition, the results suggested that lower division and senior accounting majors had higher "P" scores than other lower division and senior liberal arts majors and liberal arts majors at both levels achieved higher "P" scores than business majors at both levels. In addition, her results suggested that accounting majors at both levels had higher "P" scores than the business and liberal arts majors at similar levels. She found that the liberal arts majors at both levels had higher "P" scores than the business majors.

Bay and Greenberg (2001) replicated Ponemon (1993a) to examine his findings that a subject's "P" score on the DIT and their behavior is a quadratic relationship. Few studies that used the DIT as a research instrument examined "P" scores along with behavior. For those that tested this relationship it was assumed that the correlation between "P" score and behavior was linear. Bay and Greenberg conducted the research in a laboratory setting while Ponemon used the classroom environment. This setting serves to strengthen the results since the subjects know their behavior is being observed. Results confirm a statistically significant quadratic relationship ( $p$-value $=0.047$ ) for the entire sample but when analyzed by gender there was an unexpected difference. The results found by Bay and Greenberg appear to be the behavior effects of the $56 \%$ of the male subjects and not the $44 \%$ of the females. Females show a "marginally significant, positive linear relationship" ( $\mathrm{p}$-value $=0.076)(\mathrm{P} 375)$ and no suggestion of the quadratic 
relationship. Thus, Ponemon's findings that subjects with both low "P" scores and high "P" scores appear to behave more unethically than subjects with moderate "P" scores is supported for males. Females with high "P" scores appear to behave unethically.

\section{Chapter 3. HYPOTHESES DEVELOPMENT}

Jeffrey (1993) found that upper division students have a higher level of moral development, as measured by the "P" score, than do lower division students. These results provide general support for the stage-sequence theory of moral development advanced by Kohlberg (1969). Armstrong (1993) tested students who chose to take an elective course in ethics. She found the students post-ethics course "P" score was higher than the student's pre-ethics course "P" score. Rest (1979) found that moral reasoning is a distinct cognitive domain that can be taught. Armstrong's 1993 results might have been biased by students' familiarity with the instrument or by the fact that students with an interest in ethics might select an ethics course as an elective. Rest (1986) found that formal education at any level is the primary predictor of moral development. For students who took an ethics course as an elective, Shaub (1994) found a higher level of moral development, as measured by the DIT, than with students who did not take an ethics course. Prior research that used the Defining Issues Test as a measurement instrument did not use a control group when testing students who took an ethics course. All the student subjects in the prior research made a choice to take an ethics course; none were required to take an ethics course as a requirement for graduation. 
The present study contributes to the literature by examining the difference in DIT "P" scores between students who took an ethics course as an academic requirement for graduation at the university and students who did not take the required course. To examine the "P" scores of students who took an ethics class as an academic requirement would provide control for the self-selection bias limitation reported in the prior studies for students who took an ethics course as an elective. Based on Kohlberg's (1969) stagesequence theory of moral development that moral development increases through a series of life stages, Rest's (1986) finding that education in general is a predictor of moral development, and Shaub's (1994) finding that ethics education increases moral development, students who took an ethics course should score higher on the DIT. Thus, the first hypothesis poses a test of this assumption:

H1: As measured by the DIT score, the moral development of students at each academic level who have taken an ethics course will be greater than the moral development of students at the same academic level who have not taken this course.

Accounting is a rule-based discipline that requires those who wish to succeed to learn the rules. Schweikart (1992) finds that accounting is more of an art than a science and that "no two accountants will determine the exact same results from the same data". He finds that generally accepted accounting principles allow "too many unwritten choices" (P 473) that will require accountants to make decisions concerning the application of the various accounting principles and concepts. Students majoring in accounting learn early in their academic career of the many rules in the accounting 
profession. Shute (1979), Arlow and Ulrich (1980), Lampe and Finn (1992), and Jeffrey and Weatherholt (1996) report that accounting students and accountants have different learning styles than others in business disciplines and as a result may use a different ethical decision-making framework than other professionals. This may be because accountants are trained "using a rule-based approach" to their discipline (Shaub 1994 P22). As a result accounting students exposed to ethical concepts and principles in an ethics course should be better able than other business students to internalize this knowledge and apply it when making moral decisions. This leads to the second hypothesis:

H2: As measured by a DIT score, students majoring in accounting will possess a higher level of moral development than students majoring in nonaccounting business, and nonbusiness disciplines.

Rest's (1986) findings that education of any form is the greatest predictor of moral development has been supported by numerous studies including Ponemon and Glazer (1990), Ponemon (1992), Armstrong (1993), Shaub (1994), and Jeffrey and Weatherholt (1996). These studies report that additional education will result in higher levels of "P" scores for the respondents. Specific education in ethics was shown to be a factor in higher levels of moral development of students and practicing accountants according to St. Pierre, Nelson and Gabbin (1990), Armstrong (1993), Shaub (1994), Sweeney (1995), and Jeffrey and Weatherholt (1996).

While, higher "P" scores were reported for subjects who had specific ethics training, the significance of specific ethics education on the DIT score has not been tested 
with a control group across all academic levels. Specific ethics education for a student at a lower academic level should result in a higher DIT score than education in general for students who are at a higher academic level. This information may prove valuable for the accounting profession in light of the increasing acceptance of the 150-hour rule for licensure as a CPA. If a state requires the additional coursework beyond the Bachelors degree, but does not have a specific requirement for an ethics course, the future CPAs may not possess the moral expertise to make informed ethical decisions. Gaa (1995 P261) finds that "moral expertise increases accountants' ability to meet their fiduciary responsibilities" and to act in the best "interest of stakeholders". If an ethics course increases moral development (as measured by the "P" score) more than education in general, accounting programs and state boards of accountancy may be prompted to require specific ethics courses for accounting majors and practicing CPAs. This study thus poses the following:

H3: Students at any academic level who have taken an ethics course will have a higher level of moral development as measured by a DIT score, than students at higher academic levels that have not taken an ethics course.

\section{Chapter 4. RESEARCH METHODOLOGY}

This study was conducted at a private college in the Mid-Atlantic region of the United States. Faculty members in all disciplines of the university were asked to participate in the study and a cross section of disciplines agreed to participate. 


\subsection{Research Design and Explanatory Variables}

The research model follows:

"P" score $=\alpha_{0}+\alpha_{1}{ }^{*}$ ethics $+\alpha_{2}{ }^{*}$ level $+\alpha_{3}{ }^{*}$ major $+\alpha_{4}{ }^{*}$ age $+\alpha_{5}{ }^{*}$ gender $+\varepsilon_{1}$ where:

P-score is the principled score determined by DIT

Ethics is whether the subject has taken ethics class

Level is the academic level of the subject

Major is the students intended academic major.

Further detail on the coding of the variables is in Table 3.

TABLE 3

Variables and Coding Descriptions

\begin{tabular}{|l|l|l|}
\hline VARIABLE & CODE & DESCRIPTION \\
\hline Ethics & -1 & $\begin{array}{l}\text { No ethics course completed } \\
\text { Ethics course completed }\end{array}$ \\
\hline Level & -1 & $\begin{array}{l}\text { Upper division } \\
\text { Lower division }\end{array}$ \\
\hline Major & -1 & $\begin{array}{l}\text { Non-business } \\
\text { Nonaccounting business } \\
\text { Accounting }\end{array}$ \\
\hline Gender & +1 & Male \\
& +1 & Female \\
\hline
\end{tabular}


The Principled ("P") score on the Defining Issues Test is the dependent variable. Independent variables are ethics (the status of ethics course), level (academic level) and major (academic major). Control variables are age and gender. Age is a primary factor in the stage-sequence of CMD.

Coding of subject data followed contrast-coding procedures recommended by Cohen and Cohen (1975). Using this procedure, each independent variable is coded as a single variable with a set of contrast codes. Each subject was graded with a "P" score on their DIT. Mean "P" scores were calculated for each group by ethics status, by academic major, and by academic level. A $3 \times 2 \times 3$ Factorial Analysis of Variance was used to test the main effects for the independent variables. This is the statistical method used most often in analysis of experimental behavior according to Kerlinger (1986). Kerlinger (1986, P 228) states the method "analyzes the independent and interactive effects of two or more independent variables on a dependent variable". The dependent variable, "P" score, was analyzed according to each student's level (academic level), major (academic major), and ethics (if an ethics course was completed or not). Age and gender were tested as control variables. The DIT forms were purchased from the Center for the Study of Moral Development at the University of Minnesota.

All reported "P" scores were machine scanned and computed by the University of Minnesota. DIT scoring performs a consistency check on the reliability of the subject taking the test. This procedure is designed to identify those subjects who rate each statement with the same answer and/or those subjects who randomly mark the answer sheet without reading the questions or following the instructions. The procedure compares the answers of the twelve rating statements with answers to the four ranking 
statements that are associated with each case. If an answer sheet has more than eight inconsistencies in any story and/or more than two stories have any inconsistencies and/or more than one story has more than nine statements with the same answer, then the subject fails the consistency check and is eliminated from the sample.

In addition, the DIT calculates a Meaningless ("M") score. This represents a lofty, pretentious sounding statement that has no meaning to the story. The meaningless "M" statement is listed with the twelve rating statements that the subject evaluates. A high "M" score on the DIT suggests that the subject is not carefully reading the story but selecting a statement that sounds important to the decision statement but does not represent any stage of thinking. Rest (1986) suggests eliminating any subjects with an "M" score greater than 8 and those who fail the consistency check. Studies using the DIT have 5 to 15 percent of the sample eliminated for failing the consistency check and " $\mathrm{M}$ " score limit. This study eliminated $6.8 \%$ of the subjects.

\subsection{Subjects}

Lower division (freshmen and sophomores) were sampled from introductory accounting and business courses and a wide variety of nonbusiness Core courses required by the college such as English, Sociology, Communications, History, Mathematics and Statistics to name a few. Upper division (junior and senior) accounting majors were sampled from traditional junior and senior accounting courses including, intermediate accounting, cost accounting, taxation and auditing. Non-accounting business students were sampled from a number of business classes, such as business management, business 
law and principles of economics, required of all School of Business majors including majors in finance, marketing, management and health care administration. Nonbusiness upper division students were sampled from third and fourth year courses in a variety of majors including, education, Spanish, biology, philosophy, English, history, and engineering.

Students must take at least one course in ethics in order to graduate. Students are encouraged, but not required, to take the required ethics courses early in their academic career. In order to encourage the students to take the courses early in their academic career, each semester the college offers at least four of the ten courses that meet the graduation requirement. The required courses are in the areas of philosophy, systematic theology or moral beliefs. As a result, there are students in these classes at all academic levels from freshmen to seniors. Ninety-four females and one hundred eleven males participated in this study. Table 4 summarizes the final sample of student subjects by division level, ethics class taken or not taken, and academic major.

As seen in Table $\mathbf{4}$ some of the sample cells have a minimum number of subjects represented. However, the most obvious difference among the three academic majors is the range in ages. Despite the cell sizes, an analysis of the three majors shows that the mean age for accounting, business and other is 20.05, 19.56 and 22.51 years, respectively. There is a significant difference in the ages of the three majors $(p=0.001)$. Post hoc tests show that there is no significance in ages between accounting and business majors but other majors have a significant difference between accounting and business $(p=0.001)$. 
TABLE 4

Final Sample of Subjects

\begin{tabular}{|c|c|c|c|c|}
\hline PANEL A & & & & \\
\hline SUBJECTS & ACCOUNTING & BUSINESS & OTHER & TOTALS \\
\hline $\begin{array}{l}\text { Upper Division } \\
\text { with Ethics Class }\end{array}$ & 36 & 25 & 30 & 91 \\
\hline $\begin{array}{l}\text { Upper Division } \\
\text { without Ethics } \\
\text { Class } \\
\end{array}$ & 2 & 5 & 10 & 17 \\
\hline $\begin{array}{l}\text { Lower Division } \\
\text { with Ethics Class }\end{array}$ & 1 & 3 & 4 & 8 \\
\hline $\begin{array}{l}\text { Lower Division } \\
\text { without Ethics } \\
\text { Class } \\
\end{array}$ & 34 & 31 & 24 & 89 \\
\hline Totals & 73 & 64 & 68 & 205 \\
\hline \multicolumn{5}{|l|}{ PANEL B } \\
\hline $\begin{array}{l}\text { Upper Division } \\
\text { with Ethics Class- } \\
\text { cell specifics }\end{array}$ & $\begin{array}{l}19 \text { males } 20-27 \\
\text { years old, } 17 \\
\text { females } 20-25 \\
\text { years old. }\end{array}$ & $\begin{array}{l}13 \text { males } 19-21 \\
\text { years old, } 12 \\
\text { females } 20-22 \\
\text { years old. }\end{array}$ & $\begin{array}{l}16 \text { males } 20-47 \\
\text { years old, } 14 \\
\text { females } 21-46 \\
\text { years old. }\end{array}$ & $\begin{array}{l}48 \text { males } 19- \\
47 \text { years old, } \\
43 \text { females } 20- \\
46 \text { years old. }\end{array}$ \\
\hline $\begin{array}{l}\text { Upper Division } \\
\text { without Ethics } \\
\text { Class-cell } \\
\text { specifics }\end{array}$ & $\begin{array}{l}1 \text { male and } 1 \\
\text { female each } 21 \\
\text { years old. }\end{array}$ & $\begin{array}{l}4 \text { males } 20-21 \\
\text { years old, } 1 \\
\text { female } 20 \text { years } \\
\text { old. }\end{array}$ & $\begin{array}{l}3 \text { males } 20-24 \\
\text { years old, } 7 \\
\text { females } 20-28 \\
\text { years old. }\end{array}$ & $\begin{array}{l}8 \text { males } 20-24 \\
\text { years old, } 9 \\
\text { females } 20-28 \\
\text { years old. }\end{array}$ \\
\hline $\begin{array}{l}\text { Lower Division } \\
\text { with Ethics Class- } \\
\text { cell specifics }\end{array}$ & $\begin{array}{l}0 \text { males and } 1 \\
\text { female } 20 \text { years } \\
\text { old. }\end{array}$ & $\begin{array}{l}1 \text { male } 19 \text { years } \\
\text { old, } 2 \text { females } 20 \\
\text { years old. }\end{array}$ & $\begin{array}{l}1 \text { male } 19 \text { years } \\
\text { old, } 3 \text { females } \\
19-20 \text { years old. }\end{array}$ & $\begin{array}{l}2 \text { males } 19 \\
\text { years old, } 6 \\
\text { females } 19-20 \\
\text { years old. }\end{array}$ \\
\hline $\begin{array}{l}\text { Lower Division } \\
\text { without Ethics } \\
\text { Class-cell } \\
\text { specifics }\end{array}$ & $\begin{array}{l}19 \text { males } 18-20 \\
\text { years old, } 15 \\
\text { females } 17-20 \\
\text { years old. }\end{array}$ & $\begin{array}{l}19 \text { males } 18-25 \\
\text { years old, } 12 \\
\text { females } 18-23 \\
\text { years old. }\end{array}$ & $\begin{array}{l}15 \text { males } 17-24 \\
\text { years old, } 9 \\
\text { females } 17-32 \\
\text { years old. }\end{array}$ & $\begin{array}{l}53 \text { males } 17- \\
25 \text { years old, } \\
36 \text { females } 17- \\
32 \text { years old. }\end{array}$ \\
\hline \multicolumn{5}{|l|}{ PANEL C } \\
\hline $\begin{array}{l}\text { Seniors with } \\
\text { Ethics Class }\end{array}$ & $\begin{array}{l}23-12 \text { males, } 11 \\
\text { females }\end{array}$ & $\begin{array}{l}20-12 \text { males, } 8 \\
\text { females }\end{array}$ & $\begin{array}{l}11-3 \text { males, } 8 \\
\text { females }\end{array}$ & $\begin{array}{l}54-27 \text { males, } \\
27 \text { females }\end{array}$ \\
\hline $\begin{array}{l}\text { Seniors without } \\
\text { Ethics Class }\end{array}$ & 2- 1 male, 1 female & 3 males & $\begin{array}{l}7-1 \text { male, } 6 \\
\text { females }\end{array}$ & $\begin{array}{l}12-5 \text { males, } 7 \\
\text { females }\end{array}$ \\
\hline $\begin{array}{l}\text { Juniors with } \\
\text { Ethics Class }\end{array}$ & $\begin{array}{l}13-7 \text { males, } 6 \\
\text { females }\end{array}$ & $\begin{array}{l}5-1 \text { males, } 4 \\
\text { females }\end{array}$ & $\begin{array}{l}19-13 \text { males, } 6 \\
\text { females }\end{array}$ & $\begin{array}{l}37-21 \text { males, } \\
16 \text { females }\end{array}$ \\
\hline $\begin{array}{l}\text { Juniors without } \\
\text { Ethics Class }\end{array}$ & 0 & $\begin{array}{l}2-1 \text { male, } 1 \\
\text { female }\end{array}$ & $\begin{array}{l}3-2 \text { males, } 1 \\
\text { female }\end{array}$ & $\begin{array}{l}5-3 \text { males, } 2 \\
\text { females }\end{array}$ \\
\hline $\begin{array}{l}\text { Sophomores with } \\
\text { Ethics Class }\end{array}$ & 1 female & $\begin{array}{l}3-1 \text { male, } 2 \\
\text { female }\end{array}$ & $\begin{array}{l}4-1 \text { male, } 3 \\
\text { female }\end{array}$ & $\begin{array}{l}8-2 \text { males, } 6 \\
\text { females }\end{array}$ \\
\hline $\begin{array}{l}\text { Sophomores } \\
\text { without Ethics } \\
\text { Class }\end{array}$ & $\begin{array}{l}5-3 \text { males, } 2 \\
\text { females }\end{array}$ & $\begin{array}{l}5-1 \text { males, } 4 \\
\text { females }\end{array}$ & $\begin{array}{l}8-6 \text { males, } 2 \\
\text { females }\end{array}$ & $\begin{array}{l}18-10 \text { males, } \\
8 \text { females }\end{array}$ \\
\hline $\begin{array}{l}\text { Freshmen with } \\
\text { Ethics Class }\end{array}$ & 0 & 1 female & $\begin{array}{l}2-1 \text { male, } 1 \\
\text { female }\end{array}$ & $\begin{array}{l}3-1 \text { male, } 2 \\
\text { females }\end{array}$ \\
\hline $\begin{array}{l}\text { Freshmen without } \\
\text { Ethics Class }\end{array}$ & $\begin{array}{l}29-16 \text { males, } 13 \\
\text { females }\end{array}$ & $\begin{array}{l}25-18 \text { males, } 7 \\
\text { females }\end{array}$ & $\begin{array}{l}\text { 14- } 8 \text { males, } 6 \\
\text { females }\end{array}$ & $\begin{array}{l}68-42 \text { males, } \\
26 \text { females }\end{array}$ \\
\hline
\end{tabular}




\subsection{Instrument}

The Defining Issues Test (DIT) is the most widely used assessment technique for studying moral judgment (Trevino 1992). It has been used in more than 500 studies and has been found to possess favorable psychometric properties (Trevino 1992). The DIT produces a continuous variable, the "P" score. Principled ("P") scores represent the weight given by a subject to the moral dilemmas presented in six separate cases. Prior research (Rest 1979; Armstrong 1987; Ponemon and Gabhart 1990; Ponemon 1992) found the "P" score to be a "good surrogate measurement for locating a subject along the underlying (moral) developmental continuum" (Jeffrey 1993 P 88) between stages one and six of Kohlberg's (1969) CMD scale.

\subsection{Procedure}

All subjects were asked to complete the six-case version of the Defining Issues Test, a consent form, and a demographic questionnaire. After a brief introduction to the DIT, the subjects were asked to sign the aforementioned consent form. The students were then asked to complete all six cases and to complete the demographic form. The following demographic data were requested: age, gender, hometown, county and state, cultural/racial background, academic major, academic year, and three questions regarding their required ethics courses. Preceding the questions, the course numbers of the required courses are listed to assist the student in answering the questions. The first question asks whether they had taken any of the courses. The second question asks if they were 
currently taking one of the ethics courses. Since the students were sampled early in the semester, any student who had not completed an ethics course was included in the group of subjects who did not have an ethics course. The third question asks the student how many credit hours of the required courses they have taken. Subjects were given approximately 45 minutes to an hour to complete the entire task.

\section{RESULTS}

Descriptive statistics are presented in Table $\mathbf{5}^{3}$. As shown, the mean scores in each category, except for upper division nonbusiness subjects, are higher for students who have taken an ethics class than those who have not yet taken the class. The difference between the mean "P" score for the nonbusiness students who have taken an ethics class and those who have not is only about one-point. For subjects who have and have not taken the required ethics class, the table shows that the upper division accounting majors have higher "P" scores than the other majors and that females score higher than males. At the lower division level, the nonbusiness students had the highest mean "P" scores in the study. An interesting finding is that in the lower division, subjects who have taken an ethics class have higher minimum scores in the range; however, in the upper division students who have taken an ethics class have lower minimum scores. Due to small cell sizes for some of the categories, this may not result in statistical significance but it does merit attention to discover why the minimum score would decrease after an ethics class. 
TABLE 5

\section{DIT SCORES}

\begin{tabular}{|c|c|c|c|c|c|c|c|c|c|}
\hline \multicolumn{10}{|l|}{ PANEL A } \\
\hline \multicolumn{3}{|c|}{ Student Group } & \multicolumn{2}{|c|}{ Accounting } & \multicolumn{2}{|c|}{ Business } & $\begin{array}{l}\text { Non- } \\
\text { Business }\end{array}$ & $\begin{array}{l}\text { Gender- } \\
\text { Female }\end{array}$ & $\begin{array}{l}\text { Gender- } \\
\text { Male }\end{array}$ \\
\hline \multirow{3}{*}{$\begin{array}{l}\text { Upper } \\
\text { Division } \\
\text { Ethics } \\
\text { Class } \\
\end{array}$} & \multicolumn{2}{|c|}{ Mean } & \multicolumn{2}{|c|}{$34.8(36)$} & \multicolumn{2}{|c|}{$32.4(25)$} & $32.0(30)$ & $38.5(43)$ & $30.2(48)$ \\
\hline & \multicolumn{2}{|c|}{$\begin{array}{l}\text { Std. } \\
\text { Dev. }\end{array}$} & \multicolumn{2}{|l|}{14.85} & \multicolumn{2}{|c|}{13.55} & 9.82 & 12.97 & 11.86 \\
\hline & \multicolumn{2}{|c|}{ Range } & \multicolumn{2}{|l|}{$6.7-73.3$} & \multicolumn{2}{|c|}{$8.3-56.7$} & $10.0-51.7$ & $10.0-73.3$ & $6.7-60.0$ \\
\hline \multirow{3}{*}{$\begin{array}{l}\text { Upper } \\
\text { Division } \\
\text { No } \\
\text { Ethics } \\
\text { Class } \\
\end{array}$} & \multicolumn{2}{|c|}{ Mean } & \multicolumn{2}{|l|}{$33.4(2)$} & \multicolumn{2}{|c|}{$26.2(5)$} & $33.3(10)$ & $32.4(9)$ & $23.6(8)$ \\
\hline & \multicolumn{2}{|c|}{$\begin{array}{l}\text { Std. } \\
\text { Dev. }\end{array}$} & \multicolumn{2}{|l|}{4.74} & \multicolumn{2}{|c|}{8.81} & 8.15 & 8.25 & 9.52 \\
\hline & \multicolumn{2}{|c|}{ Range } & \multicolumn{2}{|c|}{$30.0-36.7$} & \multicolumn{2}{|c|}{$15.0-34.0$} & $25.0-45.0$ & $18.3-45.0$ & $8.3-36.7$ \\
\hline \multirow{3}{*}{$\begin{array}{l}\text { Lower } \\
\text { Division } \\
\text { Ethics } \\
\text { Class } \\
\end{array}$} & \multicolumn{2}{|c|}{ Mean } & \multicolumn{2}{|l|}{$33.9(1)$} & \multicolumn{2}{|c|}{$34.6(3)$} & $36.1(4)$ & $33.1(6)$ & $37.5(2)$ \\
\hline & \multicolumn{2}{|c|}{\begin{tabular}{|l} 
Std. \\
Dev.
\end{tabular}} & \multicolumn{2}{|l|}{ N/A } & \multicolumn{2}{|c|}{11.6} & 10.8 & 9.04 & 3.55 \\
\hline & \multicolumn{2}{|c|}{ Range } & \multicolumn{2}{|l|}{ N/A } & \multicolumn{2}{|c|}{$13.3-51.7$} & $20.0-55.0$ & $20.0-45.0$ & $35.0-40.0$ \\
\hline Lower & \multicolumn{2}{|c|}{ Mean } & $28.0(34)$ & & 28.9 & 31) & $31.5(24)$ & $29.3(36)$ & $30.2(53)$ \\
\hline $\begin{array}{l}\text { Division } \\
\text { No }\end{array}$ & $\begin{array}{l}\text { Stc } \\
\text { De }\end{array}$ & & 10.55 & & 14.02 & & 15.35 & 13.68 & 12.75 \\
\hline $\begin{array}{l}\text { Ethics } \\
\text { Class }\end{array}$ & $\mathrm{Ra}$ & & $10.0-55$ & & 11.7 & & $8.3-73.3$ & $8.3-73.3$ & $8.3-63.3$ \\
\hline PANEL B & & $\mathrm{Ac}$ & nting & Bus & & Non & ousiness & Females & Males \\
\hline $\begin{array}{l}\text { Upper } \\
\text { Division } \\
\text { Ethics Clas }\end{array}$ & & $\begin{array}{l}36 \\
20- \\
\text { old }\end{array}$ & $\begin{array}{l}\text { dents } \\
\text { years }\end{array}$ & $\begin{array}{l}25 \mathrm{~s} \\
19-2 \\
\text { old }\end{array}$ & $\begin{array}{l}\text { ents } \\
\text { ears }\end{array}$ & $\begin{array}{l}30 \mathrm{~s} \\
47 \mathrm{y}\end{array}$ & $\begin{array}{l}\text { udents 20- } \\
\text { ears old }\end{array}$ & $\begin{array}{l}43 \\
\text { females } \\
20-46 \\
\text { years old }\end{array}$ & $\begin{array}{l}48 \text { males } \\
19-47 \\
\text { years old }\end{array}$ \\
\hline $\begin{array}{l}\text { Upper } \\
\text { Division } \\
\text { No Ethics } \\
\text { Class }\end{array}$ & & & $\begin{array}{l}\text { dents } 21 \\
\text { old }\end{array}$ & $\begin{array}{l}5 \mathrm{stl} \\
20-2 \\
\text { old }\end{array}$ & ts & & $\begin{array}{l}\text { udents } 20- \\
\text { ears old }\end{array}$ & $\begin{array}{l}9 \text { females } \\
20-28 \\
\text { years old. }\end{array}$ & $\begin{array}{l}8 \text { males } \\
20-24 \\
\text { years old }\end{array}$ \\
\hline $\begin{array}{l}\text { Lower } \\
\text { Division } \\
\text { Ethics Clas }\end{array}$ & & & $\begin{array}{l}\text { lent } 20 \\
\text { old }\end{array}$ & $\begin{array}{l}3 \mathrm{st} \\
19-2 \\
\text { old }\end{array}$ & $\begin{array}{l}\text { ats } \\
\text { ears }\end{array}$ & $\begin{array}{l}4 \text { str } \\
20 y\end{array}$ & $\begin{array}{l}\text { dents } 19- \\
\text { ears old }\end{array}$ & $\begin{array}{l}6 \text { females } \\
19-20 \\
\text { years old. }\end{array}$ & $\begin{array}{l}2 \text { males } \\
19 \text { years } \\
\text { old } \\
\end{array}$ \\
\hline $\begin{array}{l}\text { Lower } \\
\text { Division } \\
\text { No Ethics } \\
\text { Class }\end{array}$ & & $\begin{array}{l}34 \\
17- \\
\text { old }\end{array}$ & $\begin{array}{l}\text { dents } \\
\text { years }\end{array}$ & $\begin{array}{l}31 \mathrm{~s} \\
18-2 \\
\text { old }\end{array}$ & $\begin{array}{l}\text { ents } \\
\text { years }\end{array}$ & $\begin{array}{l}24 \mathrm{~s} \\
32 \mathrm{y}\end{array}$ & $\begin{array}{l}\text { udents } 17- \\
\text { ears old }\end{array}$ & $\begin{array}{l}36 \\
\text { females } \\
17-32 \\
\text { years old } \\
\end{array}$ & $\begin{array}{l}53 \text { males } \\
17-25 \\
\text { years old }\end{array}$ \\
\hline
\end{tabular}

3 The numbers in parentheses are the number of subjects in the category. 
The standard deviation varies among the cells from a low of 3.55 to a high of 15.35. For most of the cells, the smaller $\mathrm{N}$ in the cell will result in a lower standard deviation. The range for many of the cells is of interest due to the finding that similar subjects, for example, upper division accounting majors who have taken an ethics class, have the lowest and highest "P" scores at 6.7 and 73.3, respectively. The mean for upper division accounting majors who have taken the ethics class is higher than for those who have not taken the class but the range is also greater for those students. Further investigation of this finding might be warranted in another study.

Table 5 shows that nonbusiness students are from a wider age range than accounting and business students. Both male and female nonbusiness students are older than students from the other academic majors are. Of considerable interest is that the mean of all the upper division nonbusiness students is 33.2 and the lower division nonbusiness students mean is 32.9. After completion of an Ethics class there does not appear to be any difference in "P" scores for students in this academic major.

H1 predicts that "P" scores for students at each academic level who have taken an ethics course will be greater than "P" scores for students at the same academic level who have not taken an ethics course. As shown in Table $6^{4}$ there is a significant main effect for Ethics with students who have taken an ethics course scoring higher $(F=6.3$, $p=0.013$ ). Hence, $\mathrm{H} 1$ is supported. This result is consistent with Rest's (1986) finding that specific ethics education increases the moral development significantly more than education in general. $\mathrm{H} 2$ predicts that students majoring in accounting will have a higher

\footnotetext{
4 All statistical analyses were done excluding approximately $10 \%$ of the outliers with similar results obtained. Outliers were "P" scores below 15 and above 65.
} 
level of moral development as measured by the "P" score than non-accounting business students and nonbusiness majors. The results presented in Table 6 do not support the hypothesis. The main effect for Academic Major is insignificant ( $F=0.83, p=0.438)$. This finding disputes the idea that accounting students will better internalize the ethical concepts learned and follow the rules better than students majoring in other disciplines. Despite the fact that accounting students have different learning styles (Shute 1979, Arlow and Ulrich 1980, Lampe and Finn 1992, and Jeffrey and Weatherholt 1996), this learning style does not appear to facilitate the application of ethical concepts in a different context. Mean "P" scores for accounting majors were 31.60 which is less than the mean "P" score for non-business majors (33.04), but higher than the mean "P" score for other business majors (29.59). These differences are insignificant.

Table 6 presents the analyses for the age and gender covariates. The Age covariate shows significant influence $(F=9.45, p=0.002)$ on a student's "P" score. This is consistent with Kohlberg's (1969) CMD Theory. However, the results do not show strong influence from Gender $(F=3.19, p=0.076)$ on "P" score. This does not support Shaub (1994) and Bay and Greenberg (2001) who found that females had a significantly higher "P" score than males. The marginally significant results of gender in this study will be further examined with additional analyses.

The results in Table 6 do not show interaction effects for ethics class and academic major $(F=0.509, p=0.602)$, ethics class and division level $(F=0.058, p=0.811)$, and academic major and division level $(F=1.224, p=0.296)$. The three-way interaction of ethics class, academic major and division level does not reveal an interaction effect $(F=0.157, p=0.855)$. 
TABLE 6

"P" SCORE ANOVA MODEL

\begin{tabular}{|l|l|l|l|l|l|}
\hline Source & Sum of Squares & DF & Mean Square & $F$ & $p$-value \\
\hline Main Effects: & & & & & \\
\hline Combined & 3191.49 & 6 & 531.91 & 3.45 & 0.003 \\
\hline Ethics Class & 972.22 & 1 & 972.22 & 6.30 & 0.013 \\
\hline Academic Level & 14.24 & 1 & 14.24 & 0.09 & 0.762 \\
\hline Academic Maior & 255.67 & 2 & 127.83 & 0.83 & 0.438 \\
\hline Covariate Age & 1457.69 & 1 & 1457.69 & 9.45 & 0.002 \\
\hline Covariate Gender & 491.66 & 1 & 491.66 & 3.19 & 0.076 \\
\hline 2-Way Interactions: & & & & & \\
\hline Ethics ${ }^{*}$ Level & 8.88 & 1 & 8.88 & 0.06 & 0.811 \\
\hline Ethics ${ }^{\text {Major }}$ & 157.17 & 2 & 78.59 & 0.51 & 0.602 \\
\hline Level ${ }^{\text {Major }}$ & 377.64 & 2 & 188.82 & 1.24 & 0.296 \\
\hline 3-Way Interaction: & & & & & \\
\hline Ethics ${ }^{*}$ Level ${ }^{*}$ Major & 49.55 & 2 & 24.27 & 0.16 & 0.855 \\
\hline Model & 3844.52 & 13 & 295.73 & 1.916 & 0.030 \\
\hline Residual & 29476.20 & 1 & 29476.20 & & \\
\hline Total & 33320.70 & 204 & 163.34 & & \\
\hline
\end{tabular}

\section{Notes for Table 6:}

"P" score $=\alpha_{0}+\alpha_{1}{ }^{*}$ ethics $+\alpha_{2}{ }^{*}$ level $+\alpha_{3}{ }^{*}$ major $+\alpha_{4}{ }^{*}$ age $+\alpha_{5}{ }^{*}$ gender $+\varepsilon_{1}$ where:

"P"score is the principled score determined by DIT

Ethics is a $-1,1$ indicator variable equal to 1 when the subject has taken an Ethics class and -1 when the subject has not taken an Ethics class

Level is a $-1,1$ indicator variable equal to 1 if the subject's academic level is lower division and -1 if the subject's level is upper division

Major is a $-1,0,1$ indicator variable equal to -1 if the subject's intended academic major is nonbusiness, 0 if the subject's intended major is nonaccounting business and 1 if the subject's intended major is accounting.

Gender is a $-1,1$ indicator variable equal to -1 if the subject's Gender is male and 1 if the subject's Gender is female. 
The third hypothesis predicts that students at any academic level, who have taken an ethics course, will have a higher "P" score than students at higher academic levels who have not taken an ethics course. Table 7 presents the results of testing the third hypothesis. This hypothesis is supported for only one level of the seven levels of comparison. Freshmen who took an ethics class had a mean "P" score of 37.23. Juniors who did not take an ethics class had a mean "P" score of 25.42. This shows a statistically significant difference in "P" scores for the two groups $(t=2.8884, p=0.034)$. In every category, with one exception, comparing the lower academic level that took an ethics class with the upper academic level that did not take an ethics class, the lower level had a higher mean "P" score. These were, however, not significantly different. The exception was a comparison of juniors who took an ethics class with seniors who did not take an ethics class. In that comparison the juniors mean "P" score was 32.82 and the seniors without an ethics class was 32.92 .

In addition to the $2 \times 2 \times 3$ Analysis of Variance performed on the "P" scores, KruskalWallis nonparametric one-way ANOVAs were conducted. This tests the null hypothesis that all the sample means are identical against the alternative that some means are larger than other sample means. Kruskal-Wallis verifies the ranking of "P" scores performed in the ANOVAs. These nonparametric tests provided results similar to those reported for the $2 \times 2 \times 3$ ANOVA analyses. 
TABLE 7

Mean Principled "P” Scores

\begin{tabular}{|c|c|c|c|c|c|}
\hline & $\frac{\text { Mean }}{\text { "P" }}$ & $\frac{\text { Cell }}{\text { size }}$ & $\begin{array}{l}\text { Standard } \\
\text { deviation }\end{array}$ & $\begin{array}{l}T \text { - } \\
\text { value }\end{array}$ & ${\underline{\mathrm{Sig}^{5}}}$ \\
\hline $\begin{array}{l}\text { Lower division with ethics } \\
\text { class }\end{array}$ & 35.09 & 19 & 10.0 & & \\
\hline $\begin{array}{l}\text { Upper division without } \\
\text { ethics class }\end{array}$ & 30.78 & 17 & 8.30 & 1.31 & 0.199 \\
\hline Freshmen with ethics class & 37.23 & 3 & 5.09 & & \\
\hline $\begin{array}{l}\text { Sophomores without } \\
\text { ethics class }\end{array}$ & 29.06 & 18 & 13.21 & 1.05 & 0.306 \\
\hline $\begin{array}{l}\text { Juniors without ethics } \\
\text { class }\end{array}$ & 25.42 & 5 & 5.54 & 2.88 & 0.034 \\
\hline $\begin{array}{l}\text { Seniors without ethics } \\
\text { class }\end{array}$ & 32.95 & 12 & 8.67 & 0.82 & 0.428 \\
\hline $\begin{array}{l}\text { Sophomores with ethics } \\
\text { class }\end{array}$ & 34.69 & 8 & 10.75 & & \\
\hline $\begin{array}{l}\text { Juniors without ethics } \\
\text { class }\end{array}$ & 25.42 & 5 & 5.54 & 1.65 & 0.117 \\
\hline $\begin{array}{l}\text { Seniors without ethics } \\
\text { class }\end{array}$ & 32.92 & 12 & 8.67 & 0.44 & 0.662 \\
\hline Juniors with ethics class & 32.82 & 37 & 10.26 & & \\
\hline $\begin{array}{l}\text { Seniors without ethics } \\
\text { class }\end{array}$ & 32.92 & 12 & 12.06 & 0.029 & 0.980 \\
\hline
\end{tabular}

The subject data was also analyzed with a general linear regression model. Results (presented in Table 8) are consistent with the findings from the $2 \times 2 \times 3$ ANOVA (Table 6). However, in this analysis the Gender variable is significant at the 0.05 level. The $r$ squared of 0.087 (Adjusted $R$-squared $=0.065$ ) and the large residual sum of squares (30407.1) show that a regression model is not a good predictor of "P" scores. The

5 -test results as measured by difference in mean "P" scores between the two groups. The $t$-test is a two-tailed test and assumes a 95\% confidence level. 
relationship examined in the model is a non-linear relationship due to the insignificant results from the Academic Major and Academic Level independent variables.

\section{Table 8}

"P" Score General Linear Regression Model

\begin{tabular}{|r|r|r|r|r|r|}
\hline Source & Sum of Squares & DF & Mean Square & $F^{6}$ & $p$-value \\
\hline Corrected model & 2913.557 & 5 & 582.711 & 3.814 & 0.003 \\
\hline Intercept & 46.285 & 1 & 46.285 & 9.083 & 0.000 \\
\hline Ethics Class & 2.542 & 1 & 2.542 & 2.123 & 0.035 \\
\hline Division Level & -0.805 & 1 & -0.805 & -0.650 & 0.516 \\
\hline Academic Major & -1.391 & 2 & -0.696 & -1.307 & 0.193 \\
\hline Age & -0.699 & 1 & -0.699 & -2.904 & 0.004 \\
\hline Gender & 1.717 & 1 & 1.717 & 1.975 & 0.050 \\
\hline Interactions & -47.606 & & & & \\
\hline Residual & 30407.100 & & & & \\
\hline Corrected total & 33320.700 & & & & \\
\hline
\end{tabular}

$R$ - squared $=0.087($ Adjusted $R$-squared $=0.065)$

\section{Notes to Table 8:}

"P" score $=\alpha_{0}+\alpha_{1}{ }^{*}$ ethics $+\alpha_{2}{ }^{*}$ level $+\alpha_{3}{ }^{*}$ major $+\alpha_{4}{ }^{*}$ age $+\alpha_{5}{ }^{*}$ gender $+\varepsilon_{1}$, where: "P"score is the principled score determined by DIT

Ethics is a $-1,1$ indicator variable equal to 1 when the subject has taken an Ethics class and -1 when the subject has not taken an Ethics class

Level is a $-1,1$ indicator variable equal to 1 if the subject's academic level is lower division and -1 if the subject's level is upper division

Major is a $-1,0,1$ indicator variable equal to -1 if the subject's intended academic major is nonbusiness, 0 if the subject's intended major is nonaccounting business and 1 if the subject's intended major is accounting.

\footnotetext{
${ }^{6} \mathrm{~F}$-statistic is reported for the corrected model but the statistics program reported $t$-test value for constant and variables.
} 
Gender is a $-1,1$ indicator variable equal to -1 if the subject's Gender is male and 1 if the subject's Gender is female.

Bay and Greenberg (2001) found that the relationship between the dependent variable, probability of ethical behavior, and the "P"score was not linear but quadratic. The data in the current study was plotted with curve estimation and tested for best model fit. After running the data with linear, quadratic, log, cubic, and power models, the power model fit the data only slightly better than the linear model. Transformation was done on the "P"scores and they were squared. The transformed data showed similar results.

Logit analysis was used to test the relationship of the DIT score to the behavior dependent variable by Bay and Greenberg (2001). This was an appropriate tool since the dependent variable was binary. However, in the current study, the dependent variable is the DIT "P"score, which is a continuous variable; thus, logit analysis is not appropriate for testing the relationship. Point biserial correlation is an appropriate analytical tool with a continuous dependent variable. Testing the dependent variable, P-score, with the independent variables, only Gender $(p=0.028)$ and Ethics $(p=0.036)$ showed statistical significance. Since the gender variable was statistically significant at the $p=0.05$ level in the regression analysis and had marginally significant results $(p=0.076)$ in the ANOVA, additional testing was conducted by running the data in Gender segregated analyses.

Male students were analyzed with the ANOVA. The results (presented in Table 9) are considerably different from the results presented for all the subjects in Table 6. Results show a statistically significant effect for Major $(p=0.003)$ and marginally significant effect for Level ( $p=0.087$ ). The strong effects for Ethics and Age that were 
seen for the all the subjects in Table 6 are not present for the male subjects. Post hoc tests were conducted for the independent variable, Major, using the Bonferroni and Tukey methods. The Bonferroni and Tukey tests are the most frequently used post hoc comparisons and both use the $t$-test as the foundation of their analysis. Both pair-wise tests showed statistically significant differences $(p=0.003)$ in the mean "P" scores between the male students who major in nonaccounting business and all other majors. No significant differences were found in the "P" scores between the accounting and business majors nor the accounting and all other majors.

TABLE 9

“P” SCORE ANOVA MODEL FOR MALES

\begin{tabular}{|l|l|l|l|l|l|}
\hline Source & Sum of Squares & DF & Mean Square & $F$ & $p$-value \\
\hline Main Effects: & & & & & \\
\hline Combined & 2164.52 & 5 & 432.91 & 3.13 & 0.012 \\
\hline Ethics Class & 21.60 & 1 & 21.60 & 0.156 & 0.693 \\
\hline Academic Level & 414.43 & 1 & 414.43 & 2.99 & 0.087 \\
\hline Academic Major & 1687.69 & 2 & 843.84 & 6.09 & 0.003 \\
\hline Covariate Age & 40.74 & 1 & 40.74 & 0.294 & 0.589 \\
\hline 2-Way Interactions: & & & & & \\
\hline Ethics* ${ }^{*}$ Level & 6.72 & 1 & 6.72 & 0.049 & 0.826 \\
\hline Ethics*Major & 173.08 & 2 & 86.54 & 0.625 & 0.537 \\
\hline Level ${ }^{*}$ Major & 299.54 & 2 & 149.77 & 1.08 & 0.343 \\
\hline 3-Way Interaction: & & & & & \\
\hline Ethics* ${ }^{*}$ Level ${ }^{*}$ Major & 39.32 & 1 & 24.27 & 0.284 & 0.595 \\
\hline Model & 2569.31 & 11 & 233.57 & 1.69 & 0.087 \\
\hline Residual & 13710.9 & 99 & 138.49 & & \\
\hline Total & 16280.2 & 110 & 148.00 & & \\
\hline
\end{tabular}


Female students were analyzed with the ANOVA. The results (presented in

Table 10) are similar to the results presented for all the subjects in Table 6 but different from the results for males (presented in Table 9). Results show a statistically significant effect for Ethics $(p=0.002)$, Age $(p=0.000)$ and marginally significant effect for Major ( $p=0.097)$. The strong effect for Major that was seen for male subjects in Table 9 is not present for the female subjects. Post hoc tests were conducted for the variable Major using the Bonferroni and Tukey methods. As noted above, the Bonferroni and Tukey tests are the most frequently used post hoc comparisons. Neither of the pair-wise tests showed statistically significant differences in the mean "P" scores among female students who major in accounting, nonaccounting business and all other majors.

\section{TABLE 10}

"P" SCORE ANOVA MODEL FOR FEMALES

\begin{tabular}{|c|c|c|c|c|c|}
\hline Source & Sum of Squares & DF & Mean Square & $F$ & $p$-value \\
\hline \multicolumn{6}{|l|}{ Main Effects: } \\
\hline Combined & 4245.38 & 5 & 849.08 & 5.87 & 0.000 \\
\hline Ethics Class & 1441.63 & 1 & 1441.63 & 9.98 & 0.002 \\
\hline Academic Level & 205.65 & 1 & 205.65 & 1.42 & 0.236 \\
\hline Academic Major & 693.29 & 2 & 346.64 & 2.39 & 0.097 \\
\hline Covariate $A g e$ & 1904.82 & 1 & 1904.82 & 9.45 & 0.000 \\
\hline \multicolumn{6}{|l|}{ 2-Way Interactions: } \\
\hline Ethics $*$ Level & 7.03 & 1 & 7.03 & 0.049 & 0.826 \\
\hline Ethics* Major & 57.58 & 2 & 28.78 & 0.199 & 0.820 \\
\hline Level*Major & 83.41 & 2 & 41.70 & 0.289 & 0.750 \\
\hline \multicolumn{6}{|l|}{ 3-Way Interaction: } \\
\hline Ethics ${ }^{*}$ Level $*$ Major & 10.69 & 1 & 10.69 & 0.074 & 0.786 \\
\hline Model & 4473.26 & 11 & 406.66 & 1.92 & 0.004 \\
\hline Residual & 11851.5 & 82 & 144.53 & & \\
\hline Total & 16324.7 & 93 & 175.54 & & \\
\hline
\end{tabular}




\section{DISCUSSION, LIMITATIONS AND FUTURE RESEARCH}

\subsection{Discussion}

The results of this study reveal that students who take an ethics course appear to have a higher level of moral development, as measured by the Defining Issues Test (DIT), than students at the same academic level who have not taken an ethics course. The Defining Issues Test provides a Principled "P" score to measure the degree that an individual assigns to principled moral considerations when deciding ethical dilemmas. The significant differences in "P" scores for university students and graduating accounting majors may be of great concern to educators, employers and society. For example, with the demand for energy growing and the opportunity to invest in new utility construction, accountants, regulators and investors should remember the Nucorp financial collapse of the early 1980s (Frazier, 1983). According to court bankruptcy papers, Chairman Richard Burns constructed a series of fictitious sales, unorthodox accounting treatments and unrealistic claims regarding the firm's oil reserves. The firm collapsed when a new $\mathrm{CFO}, \mathrm{Hal}$ Bolton, confronted Burns with evidence that had been hidden. At the time of the bankruptcy filing this was estimated to be the largest energy firm failure in United States history. This failure needs to be remembered. As California and other states rush to alleviate the energy crisis economic conditions will exist for unethical firms to take advantage of the opportunities to manipulate financial information of new energy developers to the public. 
As Table 11 shows, there may have been a general decline in the "P" scores for college students since Rest (1979) reported DIT scores from a standardization sample of the general United States population. Scores have declined in every study cited since 1979, except Shaub (1994), and the surprising fact is that Rest's scores are based on students who were on average younger than the comparative groups in the later studies. These findings appear to support the data reported in the US News and World Report article "The Cheating Game" by Kleiner and Lord (1999). In that report, students at all academic levels do not interpret downloading articles from the Internet and using them as their own work as cheating. Loftus and Smith (1999) found that the ethics of American students are not comparable to the ethics of American students a generation ago and that current students are often aided by their parents. They found that parents have often helped students with their projects and reports and in some cases have paid others to assist their children obtain higher grades in school.

In the current study, findings support Armstrong (1993) and Shaub (1994) that students who take an ethics course appear to have a higher level of moral development. Unlike the current study where all students had to have ethics courses in order to graduate, their studies were subject to possible self-selection bias of the subjects. The current study shows that at there is a statistically significant difference between students at each level who have taken at least one ethics course. Armstrong (1993) reported increased Principled scores, also known as the "P" score, for subjects who took a course on Ethics and Professionalism as part of their accounting curriculum. If accounting curricula are to be changed to comply with the 150-hour law, a course in ethics could be a required course. Armstrong (1993) reports that Arthur Andersen \& Company's Business 
Ethics Seminars for educators states that the "goal of ethics education is to enhance students moral development, as defined by Kohlberg's model".

\section{TABLE 11}

Mean Principled "P" Scores for All Students in These Studies

\begin{tabular}{|c|c|c|}
\hline Researcher & Lower Division & Seniors \\
\hline Rest (1979) & 31.8 & 42.3 \\
\hline Ponemon and Glazer $(1990)^{8}$ & 25.50 & 40.84 \\
\hline Jeffrey (1993) & 33.84 & 39.26 \\
\hline Shaub (1994) ${ }^{9}$ & $\ldots$ & 41.32 \\
\hline Bonawitz (1997) & 31.47 & 36.16 \\
\hline Bonawitz (2002) & 30.19 & 33.03 \\
\hline
\end{tabular}

As seen in Table 12, the overall "P" score by class year confirms the work of Kohlberg (1969) and Rest $(1979,1986,1990)$ that age and education are indicators of higher levels of moral development. Seniors have the highest "P" scores and the upper division has a higher "P" score than the lower division. Table $\mathbf{1 2}$ further confirms the findings reported in the ANOVA from Table 6 that despite the higher "P" score of the upper division they are not statistically significant. In addition, Table 12 supports the Table 6 finding that there is no significant difference in "P" scores for the accounting, business and nonbusiness academic majors. That finding does not support Hypothesis 2 and Jeffrey (1993) that accounting students have higher "P" scores than other majors but does tend to support Ponemon and Glazer (1990) who reported that accounting majors

\footnotetext{
${ }^{7}$ Rest scores are the means for high school seniors and college students.

8 Ponemon and Glazer used only freshmen and not freshmen and sophomores for the lower division students in their study.

9 Shaub studied senior Auditing students and practicing auditors.
} 
have lower levels of moral development as measured by the "P" score than nonaccounting majors. Students at both academic levels who were not majoring in accounting or business had higher "P" scores than accounting and business majors.

\section{Table 12}

DIT Scores of All Student Subjects by Major, Year and Level

\begin{tabular}{|c|c|c|c|c|}
\hline & Accounting & Business & Nonbusiness & All \\
\hline Upper Division & 34.767 & 28.878 & 33.195 & 33.026 \\
\hline Seniors & 33.688 & 33.463 & 33.506 & 33.573 \\
\hline Juniors & 36.671 & 21.671 & 32.260 & 31.861 \\
\hline Lower Division & 28.080 & 29.915 & 32.847 & 30.189 \\
\hline Sophomores & 32.00 & 32.087 & 30.381 & 31.338 \\
\hline Freshmen & 27.451 & 28.453 & 35.312 & 29.590 \\
\hline Total & 31.604 & 29.598 & 33.040 & 31.531 \\
\hline
\end{tabular}

The current study has mixed results on the "P" scores of accounting majors. Senior and junior accounting majors have higher "P" scores than seniors and juniors in other majors despite the finding that the differences are not statistically significant. However, the freshmen accounting majors have the lowest "P" scores of all groups in the lower division. Sophomore accounting majors have "P" scores between sophomore nonbusiness and business majors. Bonferroni ${ }^{10}$ pairwise comparisons of the means were conducted and there were no significant pairwise differences among the means of the groups.

${ }^{10}$ The critical $T$-value was 3.422 with a 0.05 rejection level. 
The third hypothesis was partially supported with a statistically significant difference in mean "P" scores found for freshmen that took an ethics class scoring higher than juniors who did not take an ethics class. For every analysis except juniors to seniors, the lower class year with an ethics class had a higher level of moral development, as measured by the "P" score, than the higher class years. This is a finding that appears to question the strength of Kohlberg's (1969) and Rest's (1979) findings that older subjects should have higher "P" scores. In addition, they reported that education has a positive correlation with higher "P" scores but they did not specify ethics education in particular. These results appear to show that ethics education in particular has a greater affect on "P" scores than education in general.

Findings based on the gender specific analyses appear to show that males and females respond differently to the effects of taking an ethics class. Males do not appear to respond to ethics classes with corresponding increases in their "P" scores. Females show statistically significant increases in their "P" scores after taking an ethics class. In addition, the differences in p-scores are not related to the female student's academic major but are related to the choice of academic major for male students. For the female students, but not the males students, age is significantly related to their p-score on the DIT. This supports Kohlberg's (1969) CMD that moral development of an individual to a higher stage is positively correlated to the moral maturity that comes as one ages.

Kohlberg's (1969) stage-sequence theory posits that the higher the developmental stage, the greater the level of moral development. While moral development does not measure the ethical behavior of an individual, it does provide a reliable scale of the cognitive process of an individual in moral decision-making. Moral development of 
future accountants is especially relevant given the rash of negative events facing the profession today caused, in part, by a litigious business environment, continued "downsizing" of major corporations, and mergers of the largest accounting firms (Ponemon 1993). Knowledge of differences in the moral development of students should alert practicing accountants and educators to potential problems resulting from a lack of moral development as measured by the Defining Issues Test.

Employers faced with a general lack of business ethics among employees (Arlow and Ulrich, 1988; Trevino, 1986; Brenner and Molander, 1977), CPA firms' training programs for accountants in the field, and authors of continuing professional education training courses for practicing accountants could benefit from the knowledge gathered in this study. Shaub (1994) reported moral reasoning ability to be associated with auditors' abilities to recognize conflicts of interest, materiality judgments, independence, and internal controls. The addition of ethics classes to professional training programs should increase the moral reasoning ability of individuals in a professional setting.

The knowledge of differences between the moral development of accounting students and all other majors may have implications for educators developing accounting curriculums to comply with the 150-hour law and with the 1989 paper on education prepared by the managing partners of the Big Six accounting firms. This 1989 paper, "Perspectives on Education: Capabilities for Success in the Accounting Profession" (Kullberg, Groves, Gladstone, Horner, Scanlon, O’Malley, Cook and Kangas) specifies general knowledge skill, including "experience in making value judgments" as a part of a student's education. Armstrong (1993) reported increased "P" scores for subjects who took a course on Ethics and Professionalism as part of their accounting program. If 
accounting curriculums are to be changed to comply with the 150 -hour law, courses in ethics could be included as required courses. Armstrong (1993 P78) reports that Arthur Andersen \& Company's Business Ethics Seminars for educators states that the "goal of ethics education is to enhance students' moral development, as defined by Kohlberg's model."

A number of studies have been done on the moral development of accountants and accounting students. Many have used the Defining Issues Test but few have examined accountants or accounting students who have taken an ethics course in a university curriculum. None of the previous studies has had a control group of subjects. The inclusion of a control group has provided stronger support for the evidence gathered from the "P" scores of the subjects. This study's results appear to confirm that an ethics course is associated with a higher "P" score on the DIT. This finding could encourage state boards of accountancy to require an ethics exam with the renewal of the CPA license, as the State of Florida does, and curriculum committees to include an ethics course as part of the curriculum for accounting students.

According to the AICPA (1995), most university accounting majors will become the employees of CPA firms. If the moral development level of these students is low compared with the level of students in other majors, the profession may need to conclude that this comparative low moral development level of the average CPA is a causative factor for the alleged acts of malfeasance that may result in malpractice suits (Bartel, 1990). This may be the starting point for the resolution of a situation that could, if not rectified, substantially change the professional status of the CPA or even destroy it; for 
example, by the regulation of the profession through government control (Armstrong, 1993).

Finally, this research may provide the additional information necessary to aid in the development of an instrument for the specific testing of the moral development of accounting majors. Armstrong (1993) developed a sample course for teaching ethics to accounting students. The cases used in this course may provide the framework to develop a specific instrument to test the moral development of accountants. The DIT is a general instrument for testing individuals. Those who seek a career in accounting may respond differently to cases relating to specific accounting and auditing situations than they do to the standard six-story DIT. Much research on moral development may be needed to learn if the accountant and accounting student are attaining the moral and ethical criteria that the profession needs in the next century.

\subsection{Limitations}

There are limitations to the current study. The results reported in this study may be affected by geographic and/or cultural differences. The subjects in the current study were at a private college in the Mid-Atlantic region. Even the moral atmosphere may differ at state universities or private universities in the same geographic region. The size of the institution may shape students results on the DIT. Students attending an institution where smaller classes are the norm may have the opportunity for greater interaction with faculty and develop cognitive skills earlier than students with little interaction with faculty. In addition, smaller classes could allow a mentoring relationship to exist for 
students and faculty that could not exist in large classes. Students who attend private universities may differ from students who attend state universities. The selection of major and courses studied may vary considerably. Faculty members who participate in this type of research may differ from faculty members who do not make their students available for research projects.

As reported by Ponemon (1992), Jeffrey (1993), Shaub (1994) and Jeffrey and Weatherholt (1996) the "DIT" score is a reliable instrument but it is only a surrogate for moral development. The moral development of an individual is shaped by many variables, some of which may not have yet have been identified by researchers. "P" scores do offer a reliable indication of a subject's moral identification with societal dilemmas and reasoning to solve these dilemmas. Since the cases posed by the moral dilemmas are not accounting focused they may not be the best tool to evaluate how accountants would resolve moral judgments involving underreporting, client violations of internal controls, or tax fraud.

The unexpected decline in 'P" scores may be a limitation. Four reasons for this decline in "P" scores are posited: a general decline in moral development, a decline in the reading comprehension of college students, the effects of the "tone at the top", and/or a lack of attention to the details of the study as exhibited by these subjects. Future research will be needed to determine the reason for the decline. 


\subsection{Future Research}

Despite the findings of this study, additional research is still needed to determine the general applicability of these findings. Will the results that an ethics course increases "P" scores hold true in different parts of the country and in varied academic institutions? Research needs to be conducted to determine if the ethics courses that will be taught to accounting majors should follow the principles of ethics from philosophy or be more adapted to the discipline of accounting. If the latter is determined to be the best course of action, should the ethics be based on case law and the AICPA Professional Code of Conduct or follow a case study approach similar to the cases of the DIT?

The gender based differences found in this study merit additional research. If males do not appear to show increased "P" scores after taking an ethics class, what process might serve to increase the moral development of male subjects? Why do males in different academic majors appear to show different levels of moral development? Do male students in accounting need a stimulus other than a classroom setting to increase their ethical understanding? Do male and female students respond differently to different instructional formats for ethics education in accounting? Since the entry-level staff in many accounting firms receive similar training this gender based difference in ethics may require the firms and accounting educators to gear ethics education differently for males and females. This would be a challenging task to assure that students and staff of both genders receive equal ethics training.

Longitudinal studies of students would allow the subjects to be tested at different stages in their professional career. This analysis would aid in understanding if the 
subject's DIT "P" score changes during their careers and at what stages these moral development changes occur. If changes in the "P" score are detected, the subjects may be responding to corporate culture (Trevino, 1992), economic pressures (Brenner and Molander, 1977), reward systems (Trevino, 1990), work related pressures (Ponemon, 1992) or a combination of these factors.

Finally, this research may provide the additional information necessary to aid in the development of an instrument for the specific testing of the moral development of accounting majors. Armstrong (1993) developed a sample course for teaching ethics to accounting students. The cases used in this course may provide the framework to develop a specific instrument to test the moral development of accountants. The DIT is a general instrument for testing individuals. Those who seek a career in accounting may respond differently to cases relating to specific accounting and auditing situations than they do to the standard six-story DIT. Much research on moral development may be needed to learn if the accountant and accounting student are attaining the moral and ethical development that the profession needs now and in the future.

The moral dilemmas and poor moral judgment in accounting practice may need to be resolved through other measures. Some of these measures might include a better screening of potential employees in the accounting professions, case studies or roleplaying involving ethical decision-making in company provided education, or formal mentoring programs in organizations committed to improving the moral judgment used in business decisions. The opportunities for accounting researchers in ethics particularly during times of economic downturns are many. 


\section{REFERENCES}

Accounting Education Change Commission (AECC). 1992. The first course in accounting: Position Statement No. Two. Bainbridge Island, Washington: AECC.

American Accounting Association (AAA), Committee on the Future Structure, Content, and Scope of Accounting Education (The Bedford Committee). 1986. Future accounting education: Preparing for the expanding profession. Issues in Accounting Education (Spring): 168-195.

AICPA (American Institute of Certified Public Accountants). 1991. Code of Professional Conduct and Bylaws. New York, NY: AICPA.

- 1995. The Supply of Accounting Graduates and the Demand for Public Accounting Recruits. New York, NY: AICPA.

Arlow, P., and T. A. Ulrich. 1980. Business Ethics, Social Responsibility and Business Students: An Empirical Comparison of Clark's Study. Akron Business \& Economic Review Fall: 17-22.

1988. A longitudinal survey of business school graduates' assessments of business ethics. Journal of Business Ethics 7: 295-302.

Armstrong, M. B. 1987. Moral development and accounting education. Journal of Accounting Education 5: 27-43.

1993. Ethics and Professionalism for CPAs. Cincinnati, Ohio: South-Western.

1993. Ethics and professionalism in accounting education: a sample course. Journal of Accounting Education 11:77-92.

Ashton, R.H., and A. H. Ashton. 1995. Perspective on judgment and decision-making research in accounting and auditing. In Judgment and Decision-Making Research in Accounting and Auditing, edited by R. H. Ashton, and A. H. Ashton, 3-25. Cambridge, England: Cambridge University Press.

Bartel, M. R. 1990. Is the moral standard also the legal standard? Pennsylvania CPA Journal 61 (1): 14-18.

Baumhart, R. C. 1961. How Ethical are Businessmen? Harvard Business Review JulyAugust: 6

Beets, S. D. 1992. The revised AICPA code of professional conduct: Current considerations. CPA Journal 62 (4): 26-32.

Bonawitz, M. F. 1997. An Analysis of the Moral Development of Students Across Major and Academic Level. Working paper. 
Bowsher, C.A. 1986. CPA Audit Quality - Many Governmental Audits Do Not Comply With Professional Standards. U. S. General Accounting Office, Report to the Chairman, Legislation and National Security Subcommittee, Committee on Government Operations House of Representatives: GAO/AFMD-86-33.

Bracken, R. M. and F. R. Urbancic. 1999. Ethics content in introductory accounting textbooks: An analysis and review. Journal of Education for Business 74 (5): 279-284.

Brenner, S. N., and E. A. Molander. 1977. Is the ethics of business changing? Harvard Business Review 55 (Jan-Feb): 57-71.

Brief, A.P., J.M. Dukerich, P.R. Brown and J.F. Brett. 1996. What's wrong with the Treadway Commission Report? Journal of Business Ethics 15 (2): 183-199

Bukics, R. M. L. and J. M. Fleming. 2000. Improper Revenue Recognition: A Problem for the Profession. Pennsylvania CPA Journal 70 (4): 9-13.

Cohen, J. and P. Cohen. 1975. Applied Multiple Regression Correlation Analysis for the Behavioral Sciences. Hillsdale, New Jersey: Lawrence Erlbaum Associates.

Cohen, J.R., L.W. Pant, and D.J. Sharp. 1998. The Effect of Gender and Academic Discipline Diversity on the Ethical Evaluations, Ethical Intentions and Ethical Orientation of Potential Public Accounting Recruits. Accounting Horizons 12 (3): 250270.

DePree, C. M., and C.T. Grant. 1999. Earnings Management and Ethical Decision Making: Choices in Accounting for Security Investments. Issues in Accounting Education 14 (4): 613-640.

Douglas, P.C., R.T. Barker, and B.N. Schwartz. 1995. An Exploratory Study of Accounting Students' Professional Attitudes: Implications for Accounting Education. Research on Accounting Ethics 1: 315-330.

Epstein, M. J., and A. D. Spalding. 1993. The Accountant's Guide to Legal Liability and Ethics. Homewood, Illinois: Business One Irwin.

Finn, D. W., L. B. Chonko, and S. D. Hunt. 1988. Ethical problems in public accounting: The view from the top. Journal of Business Ethics 7: 605-615.

Frazier, S. 1983. Financial Fiasco-How Nucorp Debacle Evolved and Shapes Up as One of the Costliest. Wall Street Journal July 5: 1A

Gaa, J. C. 1995. Moral Judgment and Moral Cognition: A Comment. Research on Accounting Ethics 1: 253-265. 
Greenman, F.E. and J. F. Sherman. 1999. Business School Ethics-An Overlooked Topic. Business and Society 104 (2): 171-177.

Hosmer, L. T. 1988. Adding Ethics to the Business Curriculum. Business Horizons 31 (4): 9-15.

Jeffrey, C. 1993. Ethical development of accounting students, non-accounting business students, and liberal arts students. Issues in Accounting Education 8 (1): 86-96. - and N. Weatherholt. 1996. Ethical development, professional commitment, and rule observance attitudes: a study of CPAs and corporate accountants. Behavioral Research in Accounting 8: 8-31.

Kerlinger, F. N. 1986. Foundations of Behavioral Research. Orlando, Florida: Holt, Rinehart and Winston, Inc.

Kleiner, C. and M. Lord. 1999. The cheating game 'Everyone's doing it,' from grade school to graduate school. U. S. News \& World Report 127 (20): 55-66.

Kohlberg, L. 1969. Stage and sequence: The cognitive development approach to socialization. In Handbook of Socialization Theory and Research, edited by D. A. Goslin, 347-480. Chicago, IL: Rand McNally.

and D. Candee. 1984. The relationship of moral judgment to moral action. In Morality, Moral Behavior and Moral Development, edited by W. M. Kurtines, and J. L. Gerwitz, 52-73. New York, NY: Wiley.

Kullberg, D. R., R. J. Groves, W. L. Gladstone, L. D. Horner, P. R. Scanlon, S.F. O'Malley, J. M. Cook, and E. A. Kangas. 1989. Perspectives on Education: Capabilities for Success in the Accounting Profession. Arthur Andersen \& CO., Arthur Young, Ernst \& Whinney, Peat Marwick Main \& CO., Coopers \& Lybrand, Price Waterhouse, Deloitte Haskins \& Sells, and Touche Ross.

Langenderfer, H.Q. and J.W. Rockness. 1989. Integrating Ethics into the Accounting Curriculum: Issues, Problems, and Solutions. Issues in Accounting Education 4 (1): 5869.

Lampe, J.C. and D. W. Finn. 1992. A Model of Auditors' Ethical Decision Processes. Auditing: A Journal of Practice and Theory 11 (Supplement): 33-59.

Lazere, C. 1997. Ethically Challenged. CFO: the magazine for chief financial officers 13 (4): 40-41.

LeClair, D. 2001. Association to Advance Collegiate Schools of Business (AACSB), Director of Knowledge Services. Correspondence between February and July. 
Levitt, A. 1998. The numbers game. Text from a speech given at New York University Center for Law and Business September 1998.

Loeb, S. E. 1988. Teaching students accounting ethics: Some crucial issues. Issues in Accounting Education (Fall): 316-329.

Loftus, M. and A. K. Smith. 1999. What started in elementary school... U.S. News \& World Report 127 (20): 66.

Mednick, R. 1987. Accountant's Liability: coping with the stampede to the courtroom. Journal of Accountancy 165 (3): 118-121.

National Commission on Fraudulent Financial Reporting (The Treadway Commission). 1987. Report on the National Commission On Fraudulent Financial Reporting. October.

Palm Beach Post. 1998. Price-Waterhouse execs accused in money scheme. May 30, $14 \mathrm{~A}$, column 2 .

Piaget, J. 1932. The Moral Judgment of the Child. London, England: Kegan Paul.

Ponemon, L. A. 1992. Auditor underreporting of time and moral reasoning: An experimental lab study. Contemporary Accounting Research 9 (1): 171-189.

- 1993. Commentary on ethical reasoning research in accounting. Ethics in Accounting American Accounting Association 18 (March): 5-7.

, and D. R. L. Gabhart. 1990. Auditor independence judgments: A cognitivedevelopmental model and experimental evidence. Contemporary Accounting Research 7 (1): $227-251$.

, and A. Glazer. 1990. Accounting education and ethical development: The influence of liberal learning on students and alumni in accounting practice. Issues in Accounting Education 5 (2): 195-208.

Rest, J. R. 1979. Development in Judging Moral Issues. Minneapolis, MN: University of Minnesota Press.

_. 1979b. Revised Manual for the Defining Issues Test. Minneapolis, MN: University of Minnesota Press.

_. 1986. Moral Development: Advances in Research and Theory. New York, NY: Praeger.

-1990. DIT Manual: Manual for the Defining Issues Test, Revised. Minneapolis, MN: University of Minnesota Press.

1994. Background: Theory and Research. In Moral Development in the Professions: Psychology and Applied Ethics, edited by J. R. Rest, and D. Narvaez, 1-26. Hillsdale, New Jersey: Lawrence Erlbaum Associates.

Sack, R. 1985. Commercialism in the profession: a threat to be managed. Journal of Accountancy 160 (4): 125-134. 
(10): 43.

1991. Integrating ethics into the accounting curriculum. Journal of Accountancy 169

St. Pierre, K.E., E. S. Nelson, and A. L. Gabbin. 1990. A Study of the Ethical Development of Accounting Majors in Relation to Other Business and Nonbusiness Disciplines. Accounting Educators' Journal 3 (1): 23-35.

Schweikart, J.A. 1992. Cognitive-Contingency Theory and the Study of Ethics in Accounting. Journal of Business Ethics 11 (5): 471-478.

Shaub, M., D. Finn, and P. Munter. 1993. The Effects of Auditors' Ethical Orientation on Commitment and Ethical Sensitivity. Behavioral Research in Accounting 5: 145-169.

. 1994. An analysis of the association of traditional demographic variables with the moral reasoning of auditing students and auditors. Journal of Accounting Education 12 (1): $1-26$.

Shute, G.E. 1979. Accounting Students and Abstract Reasonings: An Exploratory Study. Sarasota, Florida: American Accounting Association.

Sweeney, J.T. 1995. The Moral Expertise of Auditors: An Exploratory Analysis. Research on Accounting Ethics 1: 213-234.

Tie, R. 1997. SEC Renews Push for More Oversight of Auditors. Journal of Accountancy 191 (1): 16-17.

Trevino, L. K. 1986. Ethical decision making in organizations: A person-situation interactionist model. Academy of Management Review 11 (3): 601-617.

. 1990. A cultural perspective on changing and developing organizational ethics. Research in Organizational Change and Development 4: 195-230.

. 1992. Moral reasoning and business ethics: Implications for research, education, and management. Journal of Business Ethics 11: 445-459.

, and D. McCabe. 1994. Meta-learning About Business Ethics: Building Honorable Business School Communities. Journal of Business Ethics 13: 405-416

Ward, S. P., D. R. Ward, and T.E. Wilson. 1996. The Code of Professional Conduct: Instructional Impact on Accounting Students' Ethical Perceptions and Attitudes. Journal of education for business 71 (3): 147-150.

Washington Post. 2000. Watching the Watchdogs. Wednesday March 29, A24.

Wright, G.B., C.P. Cullinan, and D.M. Bline. 1997. The Relationship Between an Individual's Values and Perceptions of Moral Intensity: An Empirical Study. Behavioral Research in Accounting 9 (Supplement): 26-49. 


\section{APPENDIX A}

\section{Survey of the Field}

\begin{tabular}{|c|c|c|c|}
\hline Author & Title & Contents & Findings/Portions Usable \\
\hline $\begin{array}{l}\text { Armstrong } \\
\text { (1987) }\end{array}$ & $\begin{array}{l}\text { Moral } \\
\text { development and } \\
\text { accounting } \\
\text { education. }\end{array}$ & $\begin{array}{l}\text { Level of moral } \\
\text { development and } \\
\text { accounting education of } \\
\text { practicing CPAs. }\end{array}$ & $\begin{array}{l}\text { CPAs have DIT scores } \\
\text { comparable with adults in } \\
\text { general but lower than } \\
\text { college students or alumni. }\end{array}$ \\
\hline $\begin{array}{l}\text { Ponemon } \\
\text { and Glazer } \\
(1990)\end{array}$ & $\begin{array}{l}\text { Accounting } \\
\text { education and } \\
\text { ethical } \\
\text { development: the } \\
\text { influence of liberal } \\
\text { learning on } \\
\text { students and } \\
\text { alumni in } \\
\text { accounting } \\
\text { practice. }\end{array}$ & $\begin{array}{l}\text { Difference in moral } \\
\text { development of } \\
\text { accounting students, } \\
\text { freshmen and seniors, } \\
\text { and alumni from liberal } \\
\text { arts institution and } \\
\text { traditional state } \\
\text { university. }\end{array}$ & $\begin{array}{l}\text { Freshmen have lower DIT } \\
\text { scores than seniors. } \\
\text { Seniors and alumni at the } \\
\text { liberal arts institution have } \\
\text { higher DIT scores than } \\
\text { seniors and alumni at the } \\
\text { state university. }\end{array}$ \\
\hline $\begin{array}{l}\text { Ponemon } \\
\text { and Gabhart } \\
(1990)\end{array}$ & $\begin{array}{l}\text { Auditor } \\
\text { independence } \\
\text { judgments: a } \\
\text { cognitive- } \\
\text { developmental } \\
\text { model and } \\
\text { experimental } \\
\text { evidence. }\end{array}$ & $\begin{array}{l}\text { Partners and managers } \\
\text { from two national CPA } \\
\text { firms tested on auditors' } \\
\text { conceptions of } \\
\text { independence in the } \\
\text { framework of ethical } \\
\text { decision-making. }\end{array}$ & $\begin{array}{l}\text { Independence judgments } \\
\text { are grounded in the } \\
\text { auditor's ethical cognition } \\
\text { and are strongly influenced } \\
\text { by factors relating to } \\
\text { penalty and less influenced } \\
\text { by affiliation factors. }\end{array}$ \\
\hline $\begin{array}{l}\text { Ponemon } \\
\text { (1992) }\end{array}$ & $\begin{array}{l}\text { Auditor } \\
\text { underreporting of } \\
\text { time and moral } \\
\text { reasoning: an } \\
\text { experimental lab } \\
\text { study. }\end{array}$ & $\begin{array}{l}\text { Experimental lab study } \\
\text { of National CPA firm } \\
\text { staff auditors' } \\
\text { underreporting of time } \\
\text { budgets and moral } \\
\text { reasoning. }\end{array}$ & $\begin{array}{l}\text { Auditors with low DIT } \\
\text { scores underreport more } \\
\text { than auditors with high } \\
\text { DIT scores. }\end{array}$ \\
\hline $\begin{array}{l}\text { Armstrong } \\
\text { (1993) }\end{array}$ & $\begin{array}{l}\text { Ethics and } \\
\text { professionalism in } \\
\text { accounting } \\
\text { education: a } \\
\text { sample course. }\end{array}$ & $\begin{array}{l}\text { Pre and post test } \\
\text { comparisons of senior } \\
\text { and junior accounting } \\
\text { students who took a } \\
\text { course in ethics and } \\
\text { professionalism. }\end{array}$ & $\begin{array}{l}\text { Students who took the } \\
\text { course had a significant } \\
\text { increase in DIT scores as } \\
\text { compared with the control } \\
\text { group. }\end{array}$ \\
\hline
\end{tabular}




\begin{tabular}{|c|c|c|c|}
\hline Author & Title & Contents & Findings/Portions Usable \\
\hline $\begin{array}{l}\text { Jeffrey } \\
(1993)\end{array}$ & $\begin{array}{l}\text { Ethical } \\
\text { development of } \\
\text { accounting } \\
\text { students, non- } \\
\text { accounting } \\
\text { business students, } \\
\text { and liberal arts } \\
\text { students. }\end{array}$ & $\begin{array}{l}\text { Ethical development of } \\
\text { students in lower } \\
\text { division, freshman and } \\
\text { sophomores, and senior } \\
\text { classes majoring in } \\
\text { accounting, business and } \\
\text { liberal arts. }\end{array}$ & $\begin{array}{l}\text { Seniors have higher levels } \\
\text { of moral development than } \\
\text { lower division students do } \\
\text { and accounting majors } \\
\text { have higher levels of moral } \\
\text { development than students } \\
\text { in other majors do. }\end{array}$ \\
\hline $\begin{array}{l}\text { Shaub } \\
(1994)\end{array}$ & $\begin{array}{l}\text { An analysis of the } \\
\text { association of } \\
\text { traditional } \\
\text { demographic } \\
\text { variables with the } \\
\text { moral reasoning of } \\
\text { auditing students } \\
\text { and auditors. }\end{array}$ & $\begin{array}{l}\text { Analysis of traditional } \\
\text { demographic variables } \\
\text { with senior auditing } \\
\text { students and practicing } \\
\text { auditors at a national } \\
\text { firm. }\end{array}$ & $\begin{array}{l}\text { Gender, GPA and ethics } \\
\text { courses were positively } \\
\text { associated with higher } \\
\text { levels of moral } \\
\text { development. Age, } \\
\text { education and professional } \\
\text { experience were not } \\
\text { associated with higher } \\
\text { levels of moral reasoning. }\end{array}$ \\
\hline Gaa (1995) & $\begin{array}{l}\text { Moral Judgment } \\
\text { and moral } \\
\text { cognition: a } \\
\text { comment. }\end{array}$ & $\begin{array}{l}\text { Analysis of papers of } \\
\text { Sweeney (1995) and } \\
\text { Etherington and } \\
\text { Schulting (1995) and } \\
\text { comment on construction } \\
\text { of theoretical framework } \\
\text { for moral cognition of } \\
\text { accountants. }\end{array}$ & $\begin{array}{l}\text { Accountants are } \\
\text { performing a socially } \\
\text { defined occupational role } \\
\text { and as such, their decisions } \\
\text { and judgments have an } \\
\text { impact on people's and } \\
\text { societal welfare. }\end{array}$ \\
\hline $\begin{array}{l}\text { Douglas, } \\
\text { Barker and } \\
\text { Schwartz } \\
(1995)\end{array}$ & $\begin{array}{l}\text { An exploratory } \\
\text { study of } \\
\text { accounting } \\
\text { students' } \\
\text { professional } \\
\text { attitudes: } \\
\text { implications for } \\
\text { accounting } \\
\text { education. }\end{array}$ & $\begin{array}{l}\text { Exploratory paper that } \\
\text { examines } \\
\text { professionalism and how } \\
\text { it is expressed by seniors } \\
\text { as they prepare to enter } \\
\text { the profession. }\end{array}$ & $\begin{array}{l}\text { Results found that students } \\
\text { did not strongly identify } \\
\text { with Hall (1968) } \\
\text { theoretical theory of } \\
\text { professionalism. This may } \\
\text { reveal that students do not } \\
\text { understand concepts } \\
\text { relating to accounting } \\
\text { profession and that } \\
\text { accounting educators may } \\
\text { need to take a more active } \\
\text { role in developing identity } \\
\text { for students. }\end{array}$ \\
\hline
\end{tabular}




\begin{tabular}{|c|c|c|c|}
\hline Author & Title & Contents & Findings/Portions Usable \\
\hline $\begin{array}{l}\text { Jeffrey and } \\
\text { Weatherholt } \\
\text { (1996) }\end{array}$ & $\begin{array}{l}\text { Ethical } \\
\text { development, } \\
\text { professional } \\
\text { commitment, and } \\
\text { rule observance } \\
\text { attitudes: a study } \\
\text { of CPAs and } \\
\text { corporate } \\
\text { accountants. }\end{array}$ & $\begin{array}{l}\text { Ethical development, a } \\
\text { professional commitment } \\
\text { and rule observance } \\
\text { attitude of public } \\
\text { accountants at all levels } \\
\text { at a national firm and } \\
\text { corporate accountants at } \\
\text { Fortune } 500 \text { firms. }\end{array}$ & $\begin{array}{l}\text { Accountants with high } \\
\text { professional commitment } \\
\text { have lower DIT scores } \\
\text { than accountants with low } \\
\text { professional commitment. } \\
\text { Between and within firm } \\
\text { differences in DIT scores } \\
\text { exist for auditors from } \\
\text { national firms. }\end{array}$ \\
\hline $\begin{array}{l}\text { Wright, } \\
\text { Cullinan } \\
\text { and Bline } \\
\text { (1997) }\end{array}$ & $\begin{array}{l}\text { The relationship } \\
\text { between an } \\
\text { individual's values } \\
\text { and perceptions of } \\
\text { moral intensity: an } \\
\text { empirical study. }\end{array}$ & $\begin{array}{l}\text { Ethical decision-making } \\
\text { process involves moral } \\
\text { intensity of the issue at } \\
\text { hand, the value system of } \\
\text { the decision-maker, and } \\
\text { professional influences. } \\
\text { Student subjects tested to } \\
\text { examine differences in } \\
\text { moral values systems and } \\
\text { perceptions of moral } \\
\text { intensity. }\end{array}$ & $\begin{array}{l}\text { Results indicate that } \\
\text { among issues of lower } \\
\text { moral imperative the } \\
\text { subjects values preferences } \\
\text { affect moral intensity } \\
\text { perceptions and with issues } \\
\text { of higher moral imperative, } \\
\text { value systems do not } \\
\text { appear to influence moral } \\
\text { intensity perceptions. } \\
\text { These differences are } \\
\text { likely to influence ethical } \\
\text { decision-making process. }\end{array}$ \\
\hline $\begin{array}{l}\text { Giacomino } \\
\text { and Akers } \\
(1998)\end{array}$ & $\begin{array}{l}\text { An examination of } \\
\text { the differences } \\
\text { between personal } \\
\text { values and value } \\
\text { types of female } \\
\text { and male } \\
\text { accounting and } \\
\text { nonaccounting } \\
\text { majors. }\end{array}$ & $\begin{array}{l}\text { Prior research has shown } \\
\text { that personal values } \\
\text { affect person's behavior. } \\
\text { This research examined } \\
\text { differences between } \\
\text { accounting and } \\
\text { nonaccounting business } \\
\text { majors personal values } \\
\text { (Schwartz, 1992) and } \\
\text { value types (Schwartz } \\
\text { and Sagiv, 1995). }\end{array}$ & $\begin{array}{l}\text { Results indicate value } \\
\text { differences between } \\
\text { accounting and } \\
\text { nonaccounting majors and } \\
\text { between males and } \\
\text { females. Understanding } \\
\text { students' values and their } \\
\text { value types can benefit } \\
\text { university faculty, } \\
\text { administrators and future } \\
\text { employers. This } \\
\text { knowledge can aid in } \\
\text { teaching and training of } \\
\text { students, curriculum } \\
\text { development, and } \\
\text { employer recruiting and } \\
\text { retention. }\end{array}$ \\
\hline
\end{tabular}




\begin{tabular}{|l|l|l|l|}
\hline Author & Title & Contents & Findings/Portions Usable \\
\hline $\begin{array}{l}\text { Cohen, Pant } \\
\text { and Sharp } \\
\text { (1998) }\end{array}$ & $\begin{array}{l}\text { The effect of } \\
\text { gender and } \\
\text { academic } \\
\text { discipline } \\
\text { diversity on the } \\
\text { ethical } \\
\text { evaluations, } \\
\text { ethical intentions } \\
\text { and ethical } \\
\text { orientation of } \\
\text { potential public } \\
\text { accounting } \\
\text { recruits. }\end{array}$ & $\begin{array}{l}\text { Study to test for } \\
\text { differences in ethical } \\
\text { evaluations, intentions } \\
\text { and orientation by gender } \\
\text { and among accounting, } \\
\text { nonaccounting business } \\
\text { and liberal arts majors. }\end{array}$ & $\begin{array}{l}\text { Accounting majors were } \\
\text { found to be harsher critics } \\
\text { of cases used in research } \\
\text { than other majors. They } \\
\text { appeared to have higher } \\
\text { ethical criteria for viewing } \\
\text { questionable actions. } \\
\text { These differences conflict } \\
\text { with some earlier studies } \\
\text { but instrument used was } \\
\text { not the DIT. }\end{array}$ \\
\hline $\begin{array}{l}\text { Bay and } \\
\text { Greenberg } \\
\text { (2001) }\end{array}$ & $\begin{array}{l}\text { The relationship of } \\
\text { the DIT and } \\
\text { behavior: a } \\
\text { replication. }\end{array}$ & $\begin{array}{l}\text { Study to examine the } \\
\text { behavior of subjects } \\
\text { (dependent variable) } \\
\text { with the "P" score of } \\
\text { subject in lab experiment } \\
\text { in order to determine if } \\
\text { behavior related to "P" } \\
\text { score. }\end{array}$ & $\begin{array}{l}\text { in significant differences } \\
\text { or class categories. Male } \\
\text { subjects appear to drive } \\
\text { study results and } \\
\text { relationship is quadratic. } \\
\text { Females exhibit linear } \\
\text { increasing relationship. } \\
\text { Subjects with extreme } \\
\text { low/high "P" scores are } \\
\text { most likely to behave } \\
\text { unethically. }\end{array}$ \\
\end{tabular}




\section{Oplalons bout social Problems}

The purpose of this questionalie is to help us under tand how people think about social probleas. Different people have differeat opialons about questions of right and wong. There are no "right" answers to such probleas in the way that math problew have right answers. We would like you to tell us what you thlak bout several problea storlea.

You 111 be asked to read tory froo this booklet Then you will be asked to wark your aswers on separate aswer sheet More detils bout how to do this will follow. But it is important that you 111 in your answers on the anser sheet 1 th 2 peac11. Please ake ure the your mark completely f111s the little elrcle, that the mark is dark, and that ay erasures that you make re completely clean.

The Identiflcation Number t the top of the aswer sheet wy already be filled in when you recelve your waterlals. If not you 111 recelve special instructions about how to $f 111$ in that number.

In this questionalie you $\$ 111$ be aked to read story and theo to place marks on the nswer heet Ia order to 11lustrate how wo wld like you to do this, conslder the followiag tory:

\section{rank Mo Tre Car}

Frak Joae ba been thlakins bout buylng car. He ill

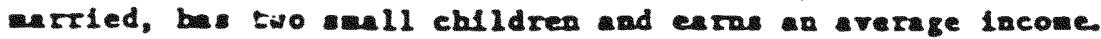

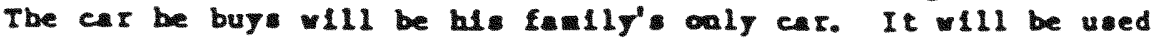
worly to get to work and drive around torn, but oowedines for vacion trips lia. In tring to declde but cir to buy, Irank Joae reallxed the there ore lot of que tion to conider. For Inteace, bould be bay larger used car or saller ne

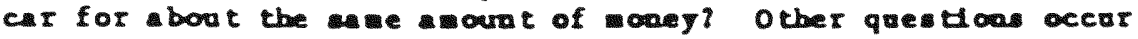
to $\mathrm{hl}$.

We note that this is not really social problem, but it 111 illustrate our instructions. After you read atory you 111 then tura to the answer sheet to find the aection that correspond to the tory. But la this sample story, we present the questons below (along w th some aple answers). Note that 11 your aswers w111 be warked on the separate asur sheet. 
First, oo the aswer sheet for ench tory you 111 be aked to ladlcate your recommendation for whe person hould co. it you cead to favor one ction or nother (even if you ge not coapletely wre), ladicate which one. If you do not favor elther ction, ark the clrcle by "can't decide."

second, read each of the 1 teas numbered 1. to 12. Thiak of the 1ssue that the item is rasigg. If that isue is laportant in waking decislon, one way or the other, thea ark the clrele by "great" If that issue Is not importent or doesn't ake sense to you, mark "no." If the issue is relevant but not critical, oak "much," "sone," or "litele" -odepeadiag on how much importace the issue has in your oplalon You may ark several 1 ters as "great" (or any other level of lmportance) - - there is no fixed number of 1 tems that cust be arked t ay ooe level.

ihird. after you have ade your arks loag the left had slde of each of the 121 tems, thea the botton you 111 be aked to choore the iteo that is the wost important consideration out of 11 the ltens priated there. PICk from ang the toms provided evea 16 you thiak that none of the 1 tems are of "great" 1 aportace. Of the 1 tems that are preseated there, pick one s the wost iportant (relative to the others), then the second wost laportant, third, and fourth not laporant.

\section{SARPLE ITLE ad SAREL AHSWTES:}

FRANK AND THE CAR: - bUy dew car o can't decide o buy used car

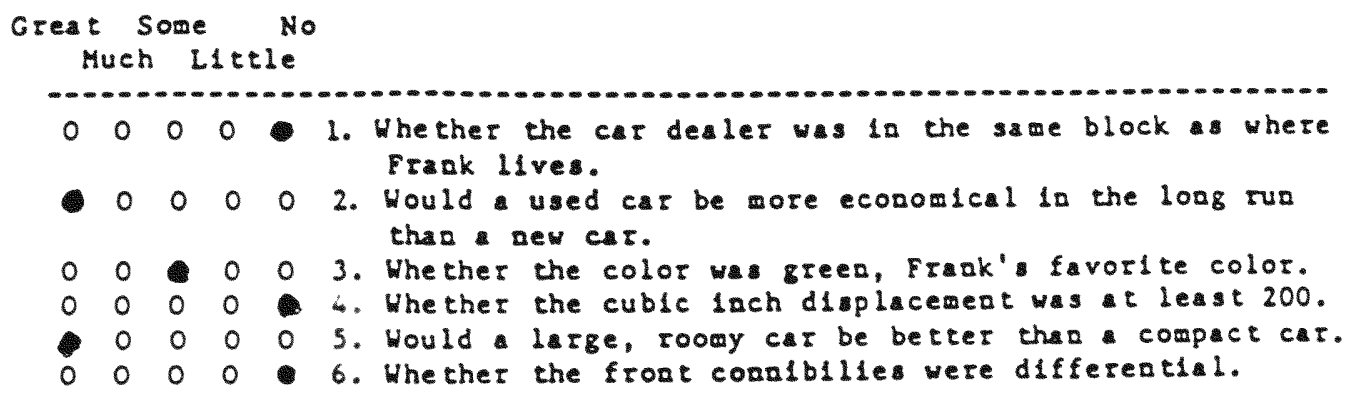

Most important item Second aost Important Third ost important Fourth oost important

$\begin{array}{llllllllllll}1 & 2 & 3 & 4 & 5 & 6 & 7 & 8 & 9 & 10 & 11 & 12 \\ 0 & 0 & 0 & 0 & 0 & 0 & 0 & 0 & 0 & 0 & 0 & 0 \\ 0 & 1 & 0 & 0 & 0 & 0 & 0 & 0 & 0 & 0 & 0 & 0 \\ 0 & 0 & 0 & 0 & 0 & 0 & 0 & 0 & 0 & 0 & 0 & 0 \\ 0 & 0 & 0 & 0 & 0 & 0 & 0 & 0 & 0 & 0 & 0 & 0\end{array}$

Note that in our sample responses, the first itew was considered irrelevant; the second ite was considered s critical isue in maklar decision; the third ite was conidered of only moderate laportance; the fourth item ws not clear to the person responding whether 200 was good or

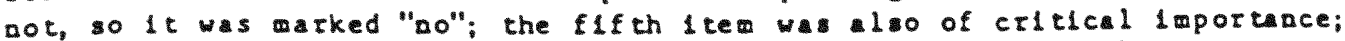

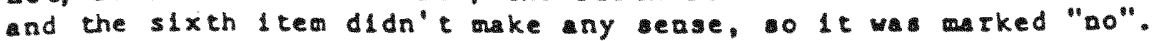

Note that the wost important 1 tew come frow one of the 1 tew arked on the far left had 1 de. In deciding between 1 tem 2 ad 5 . peroo should reread these icems, then put one of them s the nost 1 mportan, ad the other lten second, etc. 
Here is the fir to tory for your coalderiloa. Read the tory ad

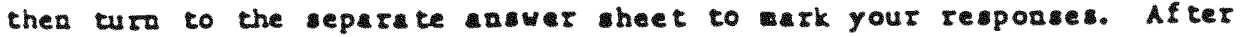
$1111 \mathrm{ag}$ in the four ost lmportant ita for the cory, retura to this booklet to read the next tory. Pleat reasar to 111 is the clrcle completely, ake dark ark, and completely ras all correctons.

\section{HETR AW IRT DADC}

In Europe women wa near death frou peclal kind of cacer. There was one drug that doctor thought abbt ave her. It wa form of radiun that druggist is the ane town had recenty discovered. The drug wa expensive to ake, but the druggist a chaglng tea tas whe the drug cost to ake. He pald $\$ 200$ for the radlun ad charged $\$ 2,000$ for 11 dose of the drug. The lck woman's huband, Helaz, weat to everyone he knew to borrow the oney, but he could only get rogether about $\$ 1,000$, whlch 1 a half of hat it cost He told the druggit that his wife wa dylag. and asked him to sell 1 t cheaper or let bio pay later. But the drugglst ald, "No, I discovered the drug and I' golag to wake money from $1 t^{\prime \prime}$ So Helaz got desperste ad began to thiak about breaklag into the ans tore to steal the drug for hi wife. Should Helaz teal the drug?

\section{ESCAPED FRISOMa}

A wan had been sentenced to prison for 10 years. After one year, however, he escaped frow pros, woved to new res of the country, and took on the nate of Thompmon. For elght years he worked hard, and gradually he saved eaough woney wo buy hilown business. He wa fali to his custowers, gave hí employee top wages, and gave most of his oun profles to charlty. Then one day, Mrs. Jones, n old nelghbor, recogalzed hi the wan wo had ecaped from prifon elght year before, ad whom the pollce had been Look1ag for. Should Mr. Jones report Mr. Thompson to the pollce and have hilo eat back to prison?

\section{VEUSPAPER}

Fred, sealor in high school, wated to publish almeographed newspaper for wdents o that he could express wany. of his oplalons. He wated to speak out aglast the use of the millury in laterantions disputes ad to peak out galastome of the achool's rules, like the rule forblddlag boy to weat loag halt.

When fred tarted his newspaper, he aked his priacipal for permis lon. The priacipal sald it would be 11 right $1 \mathrm{f}$ before every publlcation red would arn in 11 his rticles for the principal' approvi. Fred agreed and turned in everal relcles for approval. The prinelpal approved 11 of them and Fred published two issues of the paper in the next wo week.

But the prlaclpal had not expected that fred a napaper would recelve so much tention. Studeats were o excited by the paper that they began to organize protests agalast the halr regulation ad other chool rules. Aagry pareats objected to Fred's oplaloas. They phoned the principal telliag hit that the newaper w unpatriotle ad hould not be published. As a result of the rising excltemeat, the priaclpal ordered fred to top publishing. He gave s reason that fred'sctivities were disuptive to the operation of the chool. Should the priacipal top the newpaper? 


\section{Docras 's prumu}

A Lady wa dylas of cancer which could not be cured and he had only

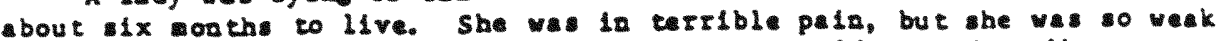

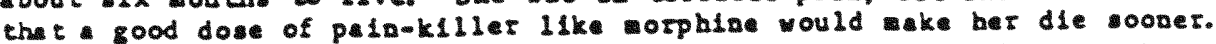
She wa delirious ad laot crezy uth paln, ad in her cals periods, he would ak the doctor to give har nougb orphine to k1ll her. She ald she couldn't tand the pain ad that he goig to die la fer gons ayway. Should the doctor glve her an overdose of corphine that would ake ber die?

\section{Tost}

Mr. Webster w the ouner and anger of g a taton. He wated to hire oother echale to help his, but good wechales were hard to fiad. The only person he found who seated to be good wechante was Mr. Lee, but he wa Chinese. While Mr. Webster hiself dida't have aything agiast Orlentals, he was frald to hIte Mr. Lee becaute may of his custoners

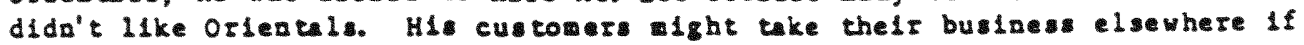
Mr. Lee was working it the gat to tor.

When Mr. Lee sked Mr. Wob ter 15 he could have the job, Mr. Webster sald that he had already hired oobody lae. But Mr. Webster really hid not hired anybody, because he could not lad anybody who wa good wechaic besldes Mr. Lee. Should Mr. Webser have hised Mr. Lee?

\section{T्यक्त TAC-Ora}

Back in the 1960 at Harvard Unlveralty chere wa cudent group called Student for a Deacrate Soc1ety (SDS). SDS tudent were aglast

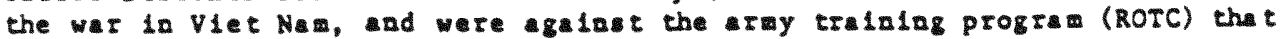

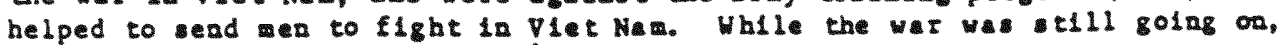
the SDS sudents demanded that harvard ead the army ROTC progra a a

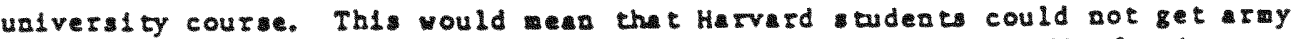
training as part of thelr regular course work and not get credit for 1 t towards thelr degree.

Harvard profesmors agred with the SDS tudents. The profemsor voted to ead the ROTC progra un universty courae. But the president of the Ualversity took different riew. He leted the the ary progra a hould stay on capul a courac.

The SDS tudeats felt thet the Preldent of the Ualversity wa not golag to pay tention to the vote of the profamors, ad wa golng to keep the ROTC progras course on capus. The SDS tudents then arched to

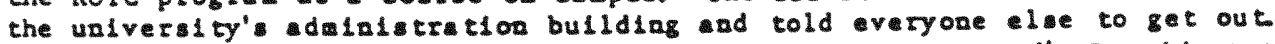
They ald they were taking over the buliding to force Harvard' President to

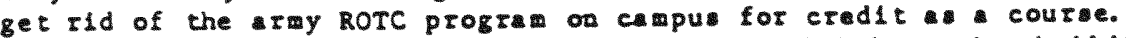

Were the sudents right to tike over the dminlitrotion buliding?

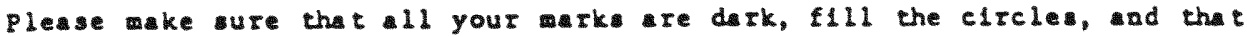
11 ersures are clean.

Tuve rod. 
000002 2. Isn't it only natural for a loving husband to care so much for his wife that he'd steal?

3. Is Heinz willing to risk getting shot as a burglar or going to jail for the chance that stealing the drug might help?

00000 4. Whether Heinz is a professional wrestler, or has considerable influence with professional wrestlers.

0000 5. Whether Heinz is stealing for himself or doing this solely to help someone else.

00000 6. Whether the druggist's rights to his invention have to be respected.

00000 7. Whether the essence of living is more encompassing than the termination of dying, socially and individually.

8. What values are going to be the basis for governing how people act towards each other.

9. Whether the druggist is going to be allowed to hide behind a worthless law which only protects the rich anyhow.

0000010 . Whether the law in this case is getting in the way of the most basic claim of any member of society.

00000 11. Whether the druggist deserves to be robbed for being so greedy and cruel.

0000012 . Would stealing in such a case bring about more total good for the whole society or not.

Most important item (1) (2) (3) (2) (5) (3) (ㄱ) (1) (1) (1) (11) (12)

Second most important (1) (2) (3) (3) (5) () (1) (2) (1) (10) (11) (12)

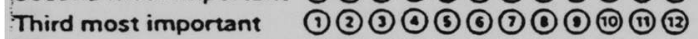

fourth most important (1) (2) (3) (ㄷ) (5) (3) (ㄱ) (1) (2) (10) (11) (12)

1. Hasn't Mr. Thompson been good enough for such a long time to prove he isn't a bad person? 00000

2. Everytime someone escapes punishment for a crime, doesn't that just encourage more crime? 00000

3. Wouldn't we be better off without prisons and the oppression of our legal system?

5. Would society be failing what Mr. Thompson should fairly expect?

6. What benefits would prisons be apart from society, especially for a charitable man?

7. How could anyone be so cruel and heartless as to send Mr. Thompson to prison?

8. Would it be fair to all the prisoners who had to serve out their full sentences if $\mathrm{Mr}$. Thompson was let off?

00000 9. Was Mrs. Jones a good friend of Mr. Thompson?

00000 10. Wouldn't it be a citizen's duty to report an escaped criminal, regardless of the circumstances?

00000 11. How would the will of the people and the public good best be served?

00000 12. Would going to prison do any good for $\mathrm{Mr}$. Thompson or protect anybody?

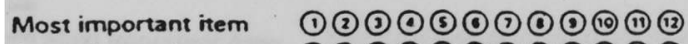

second most important (1) (2) (3) (2) (3) () (2) (2) (1) (1) (11) (12)

Third most important (1) (2) (3) (3) (3) (0) (1) $(0)$ (1) (1) (11) (12)

fourth most important (1) (2) (3) (4) (5) (1) (1) (1) (5) (1) (ii) (12)

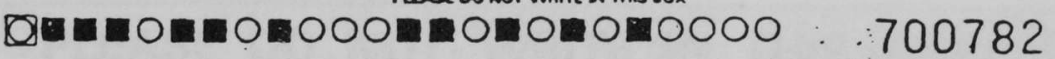




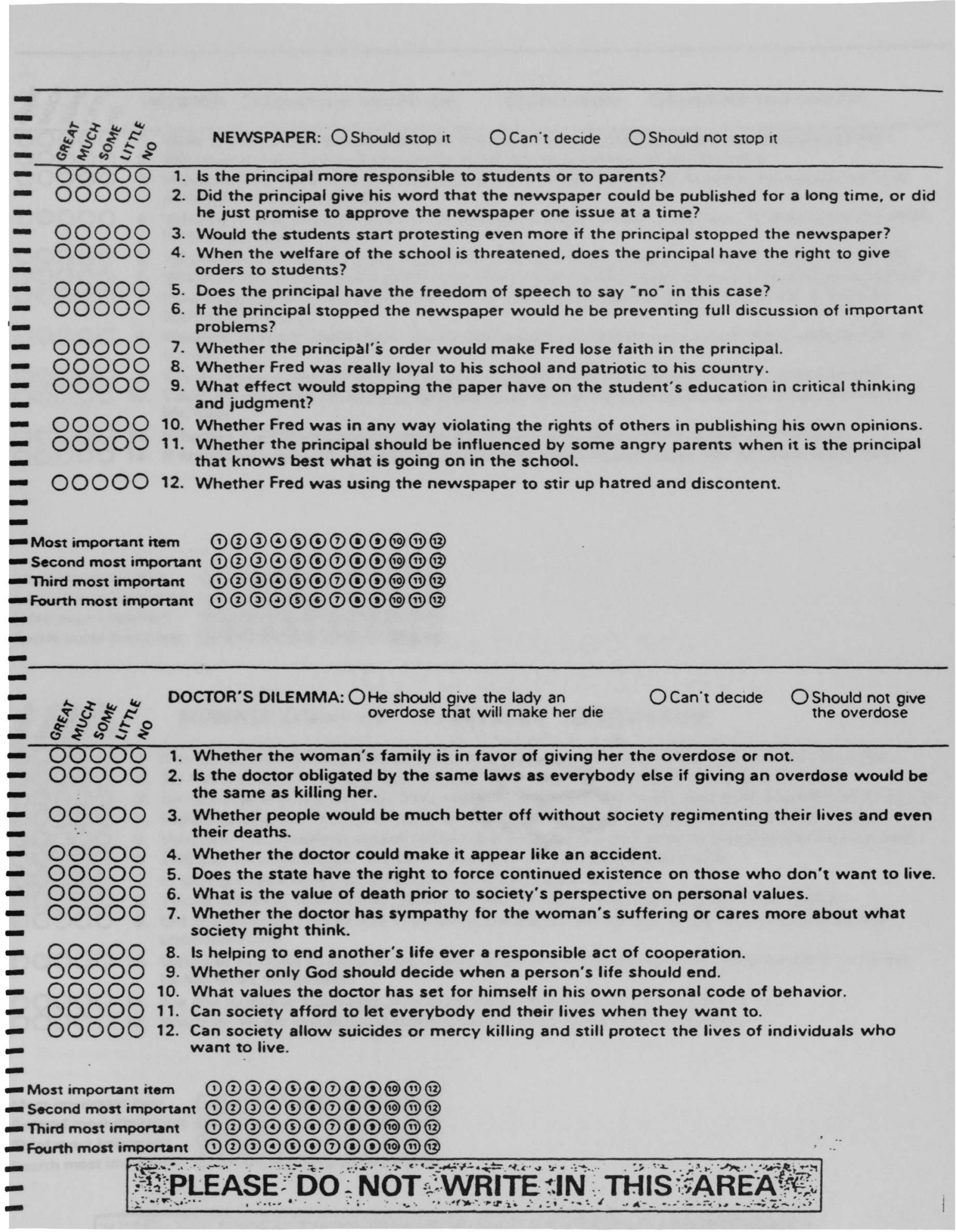


1. Does the owner of a business have the right to make his own business decisions or not?

2. Whether there is a law that forbids racial discrimination in hiring for jobs.

3. Whether $\mathrm{Mr}$. Webster is prejudiced against orientals himself or whether he means nothing personal in refusing the job.

4. Whether hiring a good mechanic or paying attention to his customers' wishes would be best for his business.

5. What individual differences ought to be relevant in deciding how society's rules are filled?

6. Whether the greedy and competitive capitalistic system ought to be completely abandoned.

7. Do a majority of people in Mr. Webster's society feel like his customers or are a majority against prejudice?

8. Whether hiring capable men like Mr. Lee would use talents that would otherwise be lost to society.

9. Would refusing the job to Mr. Lee be consistent with Mr. Webster's own moral beliefs?

10. Could Mr. Webster be so hard-hearted as to refuse the job, knowing how much it means to Mr. Lee?

00000 11. Whether the Christian commandment to love your fellow man applies to this case.

$0 \bigcirc \bigcirc \bigcirc 012$. If someone's in need, shouldn't he be helped regardless of what you get back from him?

Most important item (1) (2) (3) (4) (5) (ㄱ) (2) (ㄱ) (9) (10) (11) (12)

Second most important (1) (2) (3) (3) (5) (3) (3) (3) (2) (1) (11) (12)

Third most important (1) (2) (3) (4) (5) (ㄱ) (2) (2) (2) (10) (ii) (12)

fourth most important (1) (2) (3) (4) (5) (ㄱ) (ㄱ) (ㄱ) (3) (10) (ii) (12)

STUDENTS: O Take it over OCan't decide ONot take it over

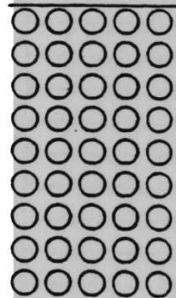

1. Are the students doing this to really help other people or are they doing it just for kicks.

2. Do the students have any right to take over property that doesn't belong to them.

3. Do the students realize that they might be arrested and fined, and even expelled from school.

4. Would taking over the building in the long run benefit more people to a greater extent.

5. Whether the president stayed within the limits of his authority in ignoring the faculty vote.

6. Will the takeover anger the public and give all students a bad name.

7. Is taking over a building consistent with principles of justice.

8. Would allowing one student take-over encourage many other student take-overs.

9. Did the president bring this misunderstanding on himself by being so unreasonable and uncooperative.

00000 10. Whether running the university ought to be in the hands of a few administrators or in the hands of all the people.

00000 11. Are the students following principles which they believe are above the law.

00000 12. Whether or not university decisions ought to be respected by students.

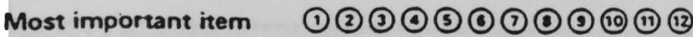

Second most important (1) (2) (3) (1) (5) (3) (1) (1) (3) (1) (ii) (12)

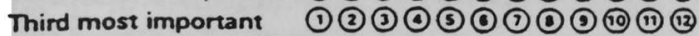

fourth most important (1) (2) (3) (4) (5) () (1) () (3) (10) (1) (12) 


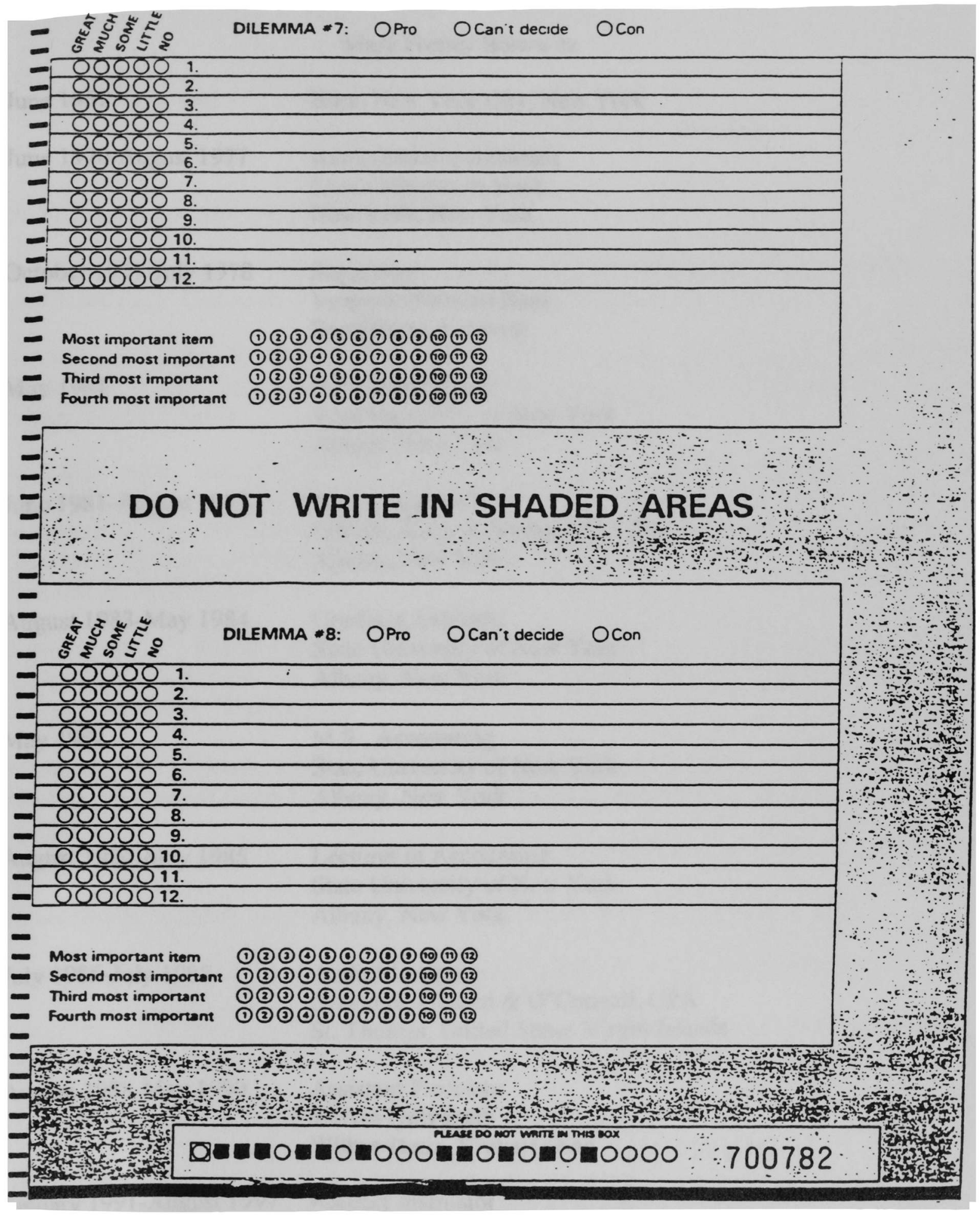


VITA

Mary Feeney Bonawitz

June 1951

Born, New York City, New York

June 1970-August 1977

Administrative Assistant

Chase Manhattan Bank

New York, New York

October 1977-July $1978 \quad$ Supervisor

Vermont National Bank

Brattleboro, Vermont

May 1981

B.S., Accounting

State University of New York

Albany, New York

June 1981-August 1983

Senior Accountant

Urbach, Kahn \& Werlin, PC, CPA

Albany, New York

August 1983-May 1984

Graduate Assistant

State University of New York

Albany, New York

May 1984

M.S., Accounting

State University of New York

Albany, New York

August 1984-May $1985 \quad$ Lecturer in Accounting

State University of New York

Albany, New York

July 1985-July 1988

Audit Manager

Brammer, Chasen \& O'Connell, CPA

St. Thomas, United States Virgin Islands

August 1988-May 1990

Assistant Professor

Wilkes University

Wilkes-Barre, Pennsylvania

January 1991-August 1997 Adjunct Instructor

Indian River Community College

Ft. Pierce, Florida 
March 1992-July 1998

Adjunct Instructor

Florida Institute of Technology

Melbourne, Florida

August 1998-present

Instructor

Pennsylvania State University-Capital College

Harrisburg, Pennsylvania

\section{PUBLICATIONS AND PRESENTATIONS}

Bonawitz, M.F. October 2001 Continuing Professional Education of two hours on FASB, GASB and EITF Update for the ASWA Annual Conference, Scottsdale, Arizona.

Bonawitz, M.F. May 2001 Continuing Professional Education of four hours International Accounting, FASB, GASB and EITF Update for the ASWA SE Regional Conference, Ft. Walton Beach, Florida.

Bonawitz, M.F. and D'Intino, R.S. June 2000. Telecommunication Equity Price Responses to Greenspan's Humphrey-Hawkins Congressional Testimony. Paper presented at the Pennsylvania Economic Association Annual Conference, Clarion University, Pennsylvania and reported in the Proceedings of the Pennsylvania Economic Association 2000 Conference.

Bonawitz, M. F., Schoenebeck, K., Hobold, H. October 1999 two hours of Continuing Professional Education on Strategic Cost Management for the ASWA Annual Conference, Seattle, Washington.

Bonawitz, M.F. March 1999 moderated Teaching Values session at Mid-Atlantic Regional Meeting of American Accounting Association in Harrisburg, Pennsylvania.

Bonawitz, M.F. (1999) From Her Point of View. Florida CPA Today, Volume 15 (1) 5-6.

Bonawitz, M.F. (1998) International Accounting. The EDGE, Volume XLVIII (6) 1.

Bonawitz, M.F. (1996) The Value of Leadership. Coordinator, Volume XLVII (4) 3.

Bonawitz, M.F. Editor, The Public Fund Digest published by the International Consortium on Governmental Financial Management from 1993-1994.

Bonawitz, M.F. Editorial board for The Woman CPA 1991.

\section{LICENSES}

Certified Public Accountant in Florida, New York, Pennsylvania and the U.S. Virgin Islands. 